\title{
Generation of Acid Mine Lakes Associated with Abandoned Coal Mines in Northwest Turkey
}

\author{
Deniz Sanliyuksel Yucel ${ }^{1} \cdot$ Nurgul Balci $^{2} \cdot$ Alper Baba $^{3}$
}

Received: 6 July 2015/ Accepted: 26 February 2016/Published online: 17 March 2016

(C) Springer Science+Business Media New York 2016

\begin{abstract}
A total of five acid mine lakes (AMLs) located in northwest Turkey were investigated using combined isotope, molecular, and geochemical techniques to identify geochemical processes controlling and promoting acid formation. All of the investigated lakes showed typical characteristics of an AML with low pH (2.59-3.79) and high electrical conductivity values (1040-6430 $\mu \mathrm{S} / \mathrm{cm})$, in addition to high sulfate $(594-5370 \mathrm{mg} / \mathrm{l})$ and metal (aluminum [Al], iron $[\mathrm{Fe}]$, manganese $[\mathrm{Mn}]$, nickel [Ni], and zinc $[\mathrm{Zn}])$ concentrations. Geochemical and isotope results showed that the acid-generation mechanism and source of sulfate in the lakes can change and depends on the age of the lakes. In the relatively older lakes (AMLs 1 through 3), biogeochemical Fe cycles seem to be the dominant process controlling metal concentration and $\mathrm{pH}$ of the water unlike in the younger lakes (AMLs 4 and 5). Bacterial species determined in an older lake (AML 2) indicate that biological oxidation and reduction of $\mathrm{Fe}$ and $\mathrm{S}$ are the dominant processes in the lakes. Furthermore, $\mathrm{O}$ and $\mathrm{S}$ isotopes of sulfate indicate that sulfate in the older mine lakes may be a product of much more complex oxidation/dissolution reactions. However, the major source of sulfate in the younger mine lakes is in situ pyrite oxidation catalyzed by $\mathrm{Fe}(\mathrm{III})$ produced by way of oxidation of $\mathrm{Fe}(\mathrm{II})$. Consistent
\end{abstract}

Deniz Sanliyuksel Yucel

denizsyuksel@comu.edu.tr

1 Department of Geological Engineering, Engineering Faculty, Canakkale Onsekiz Mart University, Canakkale, Turkey

2 Department of Geological Engineering, Faculty of Mines, Istanbul Technical University, Istanbul, Turkey

3 Department of Civil Engineering, Engineering Faculty, Izmir Institute of Technology, Izmir, Turkey with this, insignificant fractionation between $\delta^{34} \mathrm{~S}_{\mathrm{SO}_{4}}$ and $\delta^{34} \mathrm{~S}_{\mathrm{FeS}_{2}}$ values indicated that the oxidation of pyrite, along with dissolution and precipitation reactions of $\mathrm{Fe}(\mathrm{III})$ minerals, is the main reason for acid formation in the region. Overall, the results showed that acid generation during early stage formation of an AML associated with pyrite-rich mine waste is primarily controlled by the oxidation of pyrite with $\mathrm{Fe}$ cycles becoming the dominant processes regulating $\mathrm{pH}$ and metal cycles in the later stages of mine lake development.

Acidic and highly metal-loaded effluents (acid mine drainage $[\mathrm{AMD}]$ ) resulting from the exposure of pyrite and other metal sulfide minerals to weathering conditions are the principal environmental problems faced by the mining industry today (Dold and Spangerberg 2005).The formation mechanisms of AMD (e.g., oxidation of pyrite and other sulfide minerals) has been extensively studied (Nordstrom 1982; Taylor et al. 1984a, b; Evangelou and Zhang 1995; Nordstrom and Alpers 1999; Descostes et al. 2001; Schippers 2004; Blodau 2006; Balci et al. 2007, 2012). However, the details of the process causing and regulating AMD generation include complex geochemical and biogeochemical reactions involving acid generation and consumption (Nordstrom and Alpers 1999; Nordstrom 2003; Blowes et al. 2003; Blodau 2006; Cravotta 2008a, b). Much effort has been made to identify sources of acidity generation and consumption in acid mine lakes (AMLs) to develop proper remediation and management strategies (Klapper and Schultze 1995; Miller et al. 1996). Blodau (2006) overviewed a variety of processes that induce acidification of lakes in detail. Numerous studies primarily concerned with the oxidation mechanism of sulfide minerals, particularly pyrite, under acidic conditions have been 
undertaken (Balci et al. 2007, 2012). The role and effect of microbial processes on the development of AMLs in various open-pit mines have been extensively studied (Kilham et al. 1983; Mills and Herlihy 1985). An extensive body of literature exists on the characterization and reclamation of AMD from coal deposits (Growitz et al. 1985; Herlihy et al. 1990; Hedin et al. 1994; Cravotta 2008a, b).

AMLs can be created both during and at the end of operation of open-pit mines associated either with metal or coal mining. After flooding, a multitude of processes, e.g., precipitation of minerals, surface catalyzed reactions, oxidation, and reduction, many of which are catalyzed by microorganisms, can take place and cause the acidification of lakes (Miller et al. 1996; Eary 1999; Balci 2010). Therefore, elucidating the oxidation mechanisms of sulfide minerals and the prediction of water chemistry of the lakes before flooding is a key and challenging step to prevent the formation of AMLs (Eary 1998, 1999; Fennemore et al. 1998; Shevenell et al. 1999; Tempel et al. 2000; Kempton et al. 2000; Pellicori et al. 2005). In this perspective, a detailed investigation of existing acidic coal lakes may provide valuable information to determine AML-generation mechanisms. Because the development of AMLs involves hydrogeochemical processes that are regulated by regional climatic, hydrological, and geochemical conditions, investigation of AMLs from geographically distinct parts of the world may also contribute to understanding the effects of climatic conditions on the development of AMLs.

Extensive open-pit mining in the Can Coal Basin, regarded as a coal district in northwest Turkey, has caused dramatic changes in the landscape and influenced hydrological cycles. An enormous amount of mine wastes from coal-mining operations has introduced acid mine waters into peripheral streams for $>30$ years and even created permanent and seasonal AMLs with a $\mathrm{pH}$ value $<4$ in the region. The progressive and continuous oxidation of reduced sulfur (e.g., pyrite) by the ambient air and water results in the development of numerous young and relatively old AMLs with different sizes and degrees of pollution long after the abandonment of coal-mining operations in the region. AMLs in the region are more significant than AMD due to the massive water volume with low $\mathrm{pH}$ and high heavy-metal contents. Several studies have been performed on the geological, hydrogeological, and hydrogeochemical characterization of AMLs in the Can Coal Basin (Gunduz and Baba 2008; Baba et al. 2009; Okumusoglu and Gunduz 2013; Sanliyuksel Yucel 2013; Sanliyuksel Yucel and Baba 2013; Sanliyuksel Yucel et al. 2014). However, the microbial characteristics, biogeochemical processes and weathering mechanisms of reduced sulfur, which controls the formation of AMLs, have not been investigated.
The main focus of the current study was to investigate geochemical processes (e.g., oxidation of sulfur minerals) responsible for the generation of AMLs of different ages by using an integrated approach comprising geochemical, biogeochemical, and stable isotope analysis. Furthermore, the biogeochemical and stable isotope (e.g., $\delta^{18} \mathrm{O}_{\mathrm{SO}_{4}}$, $\delta^{34} \mathrm{~S}_{\mathrm{SO}_{4}}$ ) data presented for the first time in this study are important because these types of information are not available for AMLs in the Can Coal Basin. Stable isotopes are commonly used to understand oxidation mechanisms of sulfur minerals (e.g., pyrite, sphalerite) that cause acid-mine generation including mine lakes (Knoller et al. 2004; Pellicori et al. 2005; Trettin et al. 2007; Migaszewski et al. 2008; Hubbard et al. 2009) and mine tailings and waste rocks (Sracek et al. 2004; Seal et al. 2008; Smuda et al. 2008, Balci et al. 2007, 2012). Particular attention has been paid to the $\mathrm{S}$ and $\mathrm{O}$ isotopic composition of sulfate, a direct indicator and stable product of the oxidation of reduced sulfur under acidic conditions (Taylor et al. 1984a, b; Van Everdingen and Krouse 1985; Taylor and Wheeler 1994; Hubbard et al. 2009; Balci et al. 2007, 2012). The $\delta^{34} \mathrm{~S}$ and $\delta^{18} \mathrm{O}$ values of the stable product sulfate under acidic conditions may provide important insights into the oxidation mechanisms and pathways, along with source identification, of sulfides causing acid generation in various environments. The current study shows how $\delta^{34} \mathrm{~S}$ and $\delta^{18} \mathrm{O}$ values of sulfate can be used to elucidate oxidation mechanisms (biotic vs. abiotic) of sulfide minerals (e.g., pyrite) in the concerned AMLs.

\section{Study Area}

\section{Site Description}

The study area is located in Can Coal Basin, which lies approximately $65 \mathrm{~km}$ southeast of the city of Canakkale, NW Turkey (Fig. 1a). Coal exploitation in the county of Can where the AMLs are located has been active since the beginning of the 1980s. The coal-mining operations have been abandoned without any postclosure methods or rehabilitation. However, some other mining operations are still active in the region. Abandoned open-pit mines contain artificial lakes (AMLs 1 through 5) situated upstream of the Kocacay River watershed of Can County (Fig. 1b), which is rich in water resources. Local drinking and irrigation water resources derive from an alluvium aquifer that outcrops along the Kocacay River. The river is severely affected by the AMD and it is one of the most polluted stretches of river in Canakkale.

According to satellite images taken between 1977 and 2011, AMLs 2 and 3 are the oldest lakes with surface 
Fig. 1 a Location map b drainage system (Sanliyuksel Yucel et al. 2014) of the study area
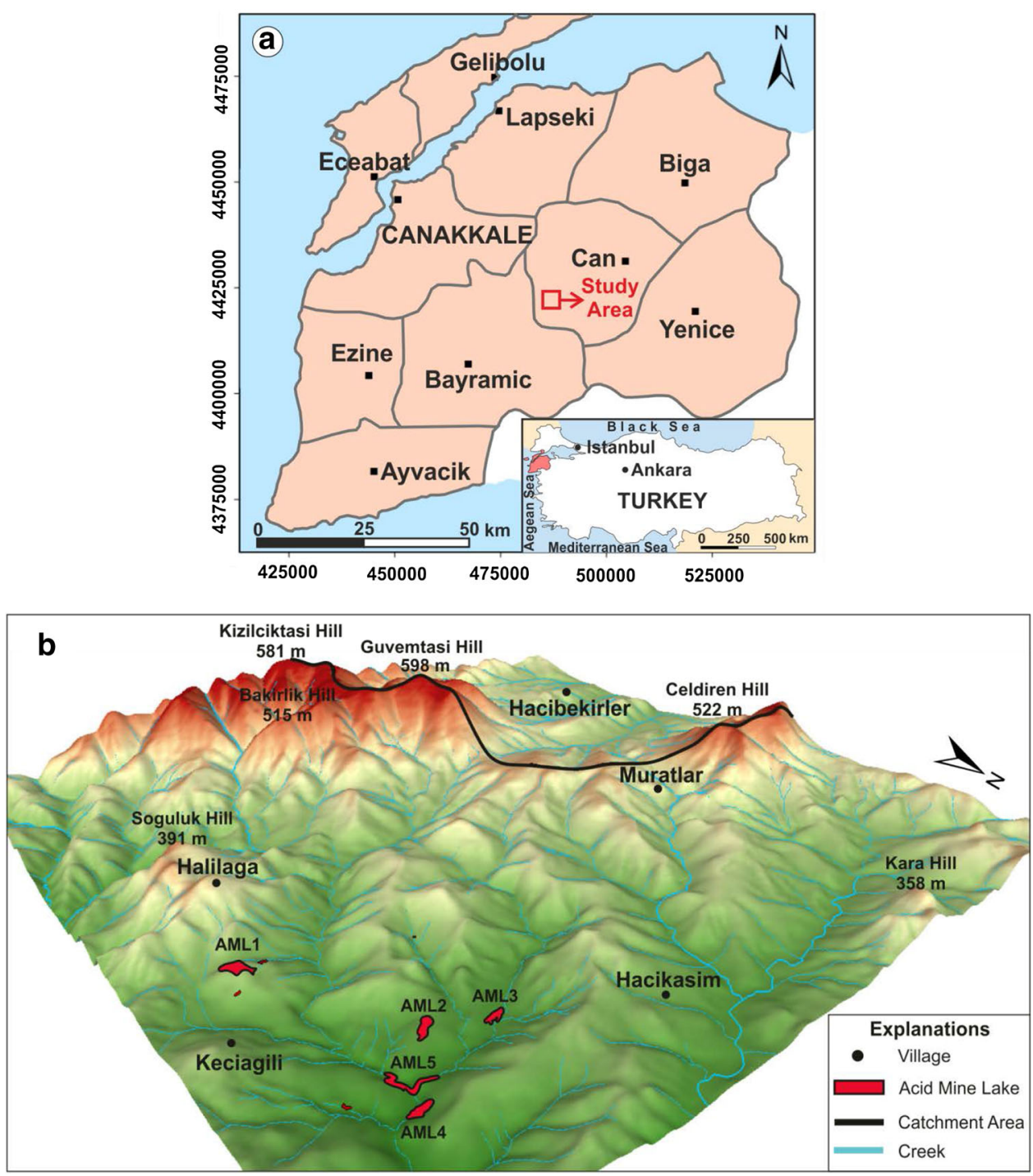

areas of 20,768 and $14,407 \mathrm{~m}^{2}$, respectively, followed by AML 1 of $31,654 \mathrm{~m}^{2}$ and finally AMLs 5 and 4 of 23,830 and $25,543 \mathrm{~m}^{2}$, respectively (Sanliyuksel Yucel et al. 2014). AML 5 formed during the late 2000s and drains through a small canal into the Katran Creek. For mining activities, AML 3 discharged into Katran Creek in November 2009 and filled again in April 2010. AML 1 was subject to a depth-profile investigation to elucidate geochemical changes in the water column. The deepest point of AML 1 is $14.2 \mathrm{~m}$; the average depth of the lake is $7.11 \mathrm{~m}$; and the perimeter was $892 \mathrm{~m}$ in September 2008 (Okumusoglu and Gunduz 2013). Areal change in AMLs with surface area $<0.3 \mathrm{~km}^{2}$ was monitored by unmanned air vehicle 6 months (June to November) in 2013. It was determined that as a result of evaporation during summer months, there is an areal decrease in AMLs and an areal increase after precipitation in spring months (Yucel et al. 2013).

\section{Geology}

The local geology of the study area where the AMLs are located mainly consists of volcanic rocks (Fig. 2). These volcanic rocks comprise acidic and agglomeratic tuff, andesite, trachyandesite, and andesitic tuff called Can volcanic rocks (Ercan et al. 1995), and these have been intensely weathered to kaolinite and limonite. Ages of volcanic rocks are approximately $23.6 \pm 0.6$ to $34.3 \pm$ 1.2 Ma (Krushensky 1976; Dayal 1984; Ercan et al. 2013). The volcanic successions of volcanic rocks are enriched with high sulfur content due to alteration processes and structural controls. Widespread and intense zones of silicified and argillic alteration can be observed in the volcanic rocks within the study area. These alteration zones are filled with disseminated pyrite and other sulfur minerals (Yigit 2012). In the Early Middle Miocene; terrestrial units were deposited simultaneously with 
Fig. 2 Geological map of the study area (modified from Sanliyuksel Yucel and Baba 2013)

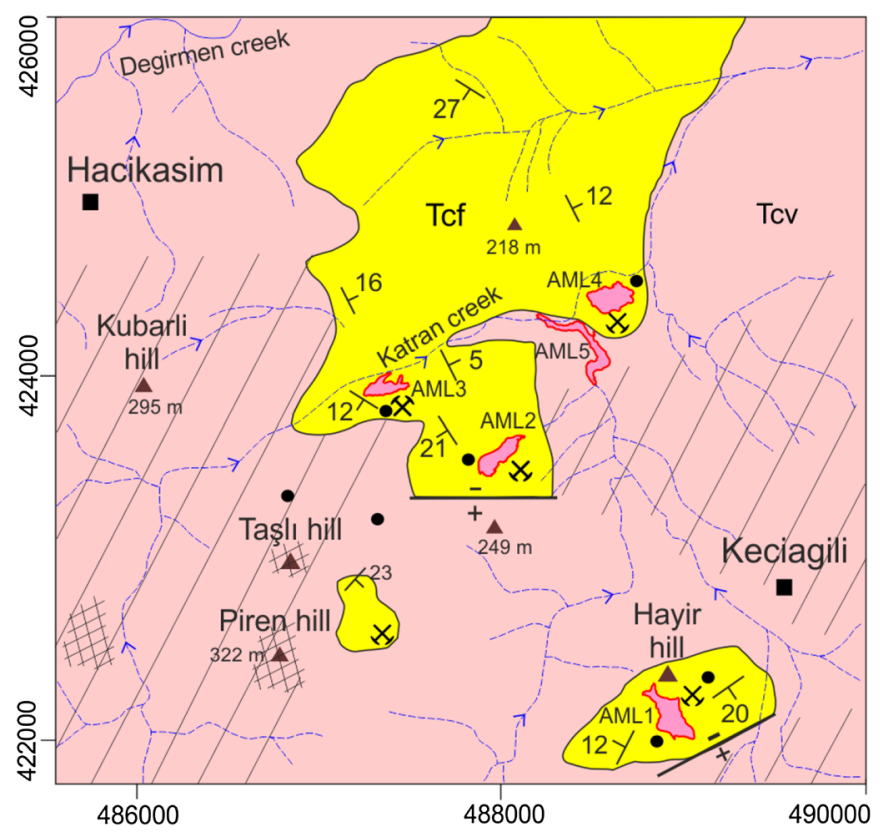

calcalkaline volcanic activity (Siyako et al. 1989). These heterogeneous terrestrial units consist of conglomerate, sandstone, claystone, coal, claystone with organic material, bituminous shale, siltstone, and tuff named the Can formation (Gurdal and Bozcu 2011), which unconformably overlies the Miocene-age volcanic rocks. According to Bozcu et al. (2008) Can formation starts with a thin clay level above brecciated volcanics and an agglomerate unit at the Keciagili Village where the AMLs developed. There are two coal levels above the clay level, which vary in thickness over short distances laterally and on average range from 4 to $6 \mathrm{~m}$ thick. Above the coal level, there is a continuous stack of alternations of green-gray clay, clayey siltstone, and sandstone, which grades into tuffites with gypsum, foliated claystone, marl, yellow-white dense leaf fossils, and diatoms (Bozcu et al. 2008). Low calorific value $(1500-4500 \mathrm{kcal} / \mathrm{kg}$ ) and high sulfur content (average approximately $6 \%$ ) coal (Gunduz and Baba 2008) has been used for local heating purposes and electricity production in the Can thermal power plant producing $2 \times 160 \mathrm{MW}$ of power.

\section{Climate and Hydrogeological Properties}

The generation of AMLs depends on climatic conditions that determine the effective type of weathering process. The study area has fertile soil and a Mediterranean climate with mild, wet winters and hot, dry summers. The longterm (1950-2014) mean annual temperature is $15.06{ }^{\circ} \mathrm{C}$ with a minimum of $-11.2{ }^{\circ} \mathrm{C}$ and a maximum of $39{ }^{\circ} \mathrm{C}$ based on data collected at the Canakkale meteorological station. July is the hottest and January the coldest month with mean temperatures of 25.1 and $6.3{ }^{\circ} \mathrm{C}$, respectively. Precipitation is usually in the form of rain with the heaviest rainfall observed during the winter months. The average annual precipitation is $634.4 \mathrm{~mm}$, and the average monthly precipitation is $52.86 \mathrm{~mm}$ according to data from 1950-2014. The amount of evaporation is greater than the precipitation except in the winter months. The average amount of annual evaporation is $1339.8 \mathrm{~mm}$. Water deficit occurs during summer months because of high evaporation and low precipitation. The annual deficit of water is $712.3 \mathrm{~mm}$ in the region. The dominant wind direction is north-northeast. The annual total average number of windy days is 161 .

The hydrogeology of the Can Coal Basin is primarily controlled by volcanic units. Silicified zones in these volcanic rocks are typically situated as a cap over the volcanic rocks (Ece et al. 2008; Baba and Gunduz 2010; Yigit 2012). The silicified volcanic rocks show fractured aquifer characteristics. Dense argillic alteration, with impervious properties due to its high clay content, can also be seen below the silicified alteration zone. These clay zones act as a barrier beneath the fractured aquifer (Baba and Gunduz 2010). In general, most of the springs in the study area surface at the boundary between the fractured aquifer (silicified zone) and the impervious boundary (argillic zone) (Sanliyuksel Yucel et al. 2014). The flow rates of springs from jointed volcanic rocks range from 0.01 to $3 \mathrm{l} / \mathrm{s}$ (Baba and Gunduz 2010; Sanliyuksel Yucel 2013). Flow rates obtained from pumping wells in volcanic rocks range from 0.2 to 0.7 1/s (SRK 2012). Hydraulic conductivity 
values of volcanic rocks range from $1 \times 10^{-7}$ to $1 \times 10^{-8} \mathrm{~m} / \mathrm{s}$, and this value indicates that the volcanic rocks have low permeability or are impermeable (SRK 2012). Generally clay alteration of volcanic rocks has a high storage capability, but this part of the volcanic unit is not a good aquifer. In addition, Can formation outcrops, with a less-permeable unit, and flow rates of springs from this sedimentary unit range from 0.01 to $0.5 \mathrm{l} / \mathrm{s}$ (Sanliyuksel Yucel 2013). The depth of pumping wells in the Can formation ranges from 100 to $150 \mathrm{~m}$, and the flow rates from these wells range from 1 to $1.5 \mathrm{l} / \mathrm{s}$ (Baba et al. 2009). The bottom of the AMLs are impermeable because of clayey level, and lake water level fluctuate due to variations in seasonal precipitation pattern. Atmospheric conditions, especially evaporation and drainage patterns and groundwater leakage, also effects areal change of AMLs.

\section{Materials and Methods}

\section{Field Methods}

All water samples from AMLs (AMLs 1 through 5) were collected in July 2010 to 2011 and March 2011 to 2012. For each lake, four water samples were collected from the surface of the lakes. AML 2, the oldest lake, was subject to a detailed investigation in July 2010. Determination of the perimeter and surface area of AML 2 coordinates of lake surface boundary was determined by Global Positioning System measurements with an average accuracy of $\pm 4 \mathrm{~m}$. Bathymetry measurements were performed at 35 different points of the lake to create a bathymetry map of the lake using a $4 \mathrm{~m}$-long fiberglass boat. These data were transferred to a geographic information system database ArcGIS v9.3 to create a map and bathymetric contours of the lake during July 2010 . There was a $235 \mathrm{~m}$-long transect $\left(A-A^{\prime}\right)$ across the longest part of the lake with an average interval of every $15 \mathrm{~m}$ for sampling. Field parameters were measured at a total of 48 different points, and 24 water samples were collected from different depths $(0.1,3,6,9$ and $12 \mathrm{~m})$ of the lake for major- and trace-element analyses. Water samples were collected from all stations with a Niskin sampling bottle (HydroBios) of 51 capacity, which was made from hard plastic material.

Parameters were measured in the field, including $\mathrm{pH}$, redox potential $(\mathrm{Eh}[\mathrm{mV}])$, temperature $\left(\mathrm{T}\left[{ }^{\circ} \mathrm{C}\right]\right)$, electrical conductivity (EC $[\mu \mathrm{S} / \mathrm{cm}])$, dissolved oxygen (DO $[\mathrm{mg} / \mathrm{l}])$, total dissolved solids (TDS [mg/l]), and salinity (Sal [\%]), using a WTW 3410 multiparameter probe. All waterquality samples were filtered on the site with a sterile syringe and single-use membrane filters $(0.45 \mu \mathrm{m}$ Millipore) and stored in 50- and 500-ml polyethylene bottles and refrigerated at $4{ }^{\circ} \mathrm{C}$ until further analysis. The 50-ml samples were acidified with $2 \% \mathrm{HNO}_{3}(\mathrm{v} / \mathrm{v})$ acid on collection and were used for element analysis. The 500-ml samples were used for anion and cation analysis. For oxygen-18 $\left(\delta^{18} \mathrm{O}\right)$, deuterium $\left(\delta^{2} \mathrm{H}\right)$, and tritium $\left(\delta^{3} \mathrm{H}\right)$ analysis, all lake water samples were collected seasonally (July 2011 and March 2012) and kept at $4{ }^{\circ} \mathrm{C}$ until further analysis. Rain and snow samples were collected during the field studies. A random sampling technique was employed in collecting rain and snow samples. Rain was collected using large plastic buckets. Buckets were rinsed with deionized (DI) water and placed $2 \mathrm{~m}$ above the ground level to avoid contamination from soil-intercepted rain. Snow samples were collected at $10-\mathrm{cm}$ depth. After collection, rain and snow samples were refrigerated and transported to the laboratory for $\delta^{18} \mathrm{O}, \delta^{2} \mathrm{H}$, and $\delta^{3} \mathrm{H}$ analyses. Filtered and unacidified water samples were also collected for $\delta^{18} \mathrm{O}$ and $\delta^{34} \mathrm{~S}$ analysis of dissolved $\mathrm{SO}_{4}{ }^{2-}$.

\section{Hydrogeochemical Analysis}

Water samples were analyzed for major and trace elements using an inductively coupled plasma-mass spectrometer (ICP-MS), and $\mathrm{SO}_{4}{ }^{2-}$ and $\mathrm{Cl}^{-}$were analyzed by ion chromatography (IC) at AcmeLabs (Canada). Acidity was measured as methyl orange acidity with digital titrator (APHA 2310 titration method), and Fe(II) was determined by ferrozine spectrophotometric method using a Hach Lange DR2800 spectrophotometer in the Geochemistry Laboratory at Canakkale Onsekiz Mart University. Fe(III) was computed as the difference between $\mathrm{Fe}(\mathrm{t})$ and $\mathrm{Fe}(\mathrm{II})$.

$\delta^{18} \mathrm{O}$ and $\delta^{2} \mathrm{H}$ content of filtered and unacidified water samples were analyzed at Hacettepe University Isotope and Environmental Laboratory, Turkey. $\delta^{3} \mathrm{H}$ analyses were performed with respect to IAEA Dead Water $\left(\delta^{3} \mathrm{H}=0\right.$ tritium units [TU]) and NIST-SRM-4926 E (Standard Reference Material [National Institute of Standards and Technology]) by means of an ultra low-level liquid-scintillation counting technique after alkaline electrolytic enrichment by electrolysis (1220 QUANTULUS, PerkinElmer) at Hacettepe University Geological Engineering Department Tritium Laboratory, Turkey.

For $\delta^{18} \mathrm{O}$ and $\delta^{34} \mathrm{~S}$ analysis, dissolved sulfate was precipitated from filtered and unacidified water as $\mathrm{BaSO}_{4}$. To prevent the formation of $\mathrm{BaCO}_{3}$, a few drops of concentrated $\mathrm{HCl}$ were added into water before addition of $10 \mathrm{ml}$ of a $10 \%$ (weight [wt/wt]) $\mathrm{BaCl}_{2}$ solution. The obtained precipitate of $\mathrm{BaSO}_{4}$ was allowed to settle overnight. The $\mathrm{BaSO}_{4}$ precipitate was filtered $(0.2 \mu \mathrm{m}$ Millipore) and washed first with $100 \mathrm{ml}$ of $1 \mathrm{~N} \mathrm{HCl}$, then rinsed three times with a total of $500 \mathrm{ml}$ of DI water. The $\mathrm{BaSO}_{4}$ samples were dried and homogenized by grinding. For final purification before $\delta^{34} \mathrm{~S}$ and $\delta^{18} \mathrm{O}$ analysis, the samples 
were baked at $500{ }^{\circ} \mathrm{C}$ for $2 \mathrm{~h}$ to remove possible organic contaminants as described elsewhere (Mandernack et al. 2000; Balci et al. 2012).

Sulfur and oxygen isotope ratios of samples were determined by continuous flow isotope ratio mass spectrometry using an elemental analyzer $\left(\delta^{34} S\right)$ or a ThermoFinnigan TC/EA at $1450{ }^{\circ} \mathrm{C}\left(\delta^{18} \mathrm{O}\right)$ coupled to a gas source isotope ratio mass spectrometer at Isotech Laboratories, USA. The oxygen and sulfur isotope results are expressed relative to Vienna Standard Mean Ocean Water (VSMOW) and Vienna Canyon Diablo Troilite (V-CDT), respectively, using the standard $\delta$ notation. Delta values can be calculated using the following equation:

$\delta^{34} \mathrm{~S}$ or $\delta^{18} \mathrm{O}$ in permil $=\left[\left(R_{\text {sample }}-R_{\text {standard }}\right)-1\right] \times 10^{3}$,

where $R_{\text {sample }}$ is the heavy to the light isotope $\left({ }^{34} \mathrm{~S} /{ }^{32} \mathrm{~S}\right.$ or ${ }^{18} \mathrm{O} /{ }^{16} \mathrm{O}$ ) measured for the sample, and $R_{\text {standard }}$ is the equivalent ratio for the standard (Sulzman 2007).

Mineralogical analyses of rock and mine waste samples were performed by X-ray diffraction (XRD) using Philips PW 1830 at the General Directorate of Mineral Research and Exploration (MTA [Turkish abbreviation]) Analysis Laboratories. Scanning electron microscopy (SEM) (FEI Philips XL30-SFEG) coupled with energy-dispersive X-ray spectrometry (EDX) was analyzed at the Center for Material Science in Izmir Institute of Technology, Turkey.

\section{Microbiological Analysis}

Sediment samples from a depth of 1 and $6 \mathrm{~m}(n=2)$ from AML 2 were collected for molecular analysis of microbial populations in October 2012. The sediment samples were obtained by Ekman bottom grab sampler and subsequently transported into sterile single-use 50 -ml centrifuge tubes using a sterile spatula and stored at $-20^{\circ} \mathrm{C}$ until further microbiological analysis. Microbiological analysis was performed according to the methods applied by Balci et al. (2015). Shortly thereafter, genomic DNA from the sediment samples was extracted by using the MoBio UltraClean Microbial DNA Isolation Kit (Catalogue No. 12224-50). Total bacterial DNA obtained using the Fast DNA Spin Kit for Soil (Catalogue No. 6560-200, MPBio) was eluted in $50 \mu \mathrm{l}$ of Tris-EDTA buffer. After these steps, the amount of DNA of the samples was estimated based on agarose gel (1\%) electrophoresis and EZ vision staining (Catalogue No. N472-KIT).

Microbial diversity of the sediment samples was determined by the $16 \mathrm{~S}$ rDNA UARR polymerase chain reaction (PCR) method (Li et al. 1999; Menekse 2012; Balci et al. 2015). A pair of universal primers namely, pA-F (5'-AGA GTTTGATCCTGGCTCAG-3 ${ }^{\prime}$ ) and pH-R (5'-AAGGAGG TGATCCAGCCGCA- $3^{\prime}$ ) were used for amplification ( $\mathrm{Li}$ et al. 1999). PCR products were visualized by agarose gel (1\%) electrophoresis and purified by ROCHE High Pure PCR Product Purification Kit (Catalogue No. 11732668 001) according to the manufacturer's suggested protocol.

Purified PCR products carrying the $16 \mathrm{~S}$ rDNA regions of microorganisms were cloned to use with the TOPO TA Cloning Kit (catalogue no. K4500-01, Invitrogen), and 20 positive clones were selected according to the blue-white screening method (Menekse 2012; Balci et al. 2014). White colonies $(n=25)$ were picked and inoculated in $15-\mathrm{ml}$ tubes containing $3 \mathrm{ml}$ of LB broth and $3 \mu \mathrm{l}$ of ampicillin stock solution $(0.1 \mathrm{~g} / \mathrm{ml}$ ampicillin). Then they were incubated by shaking at $37{ }^{\circ} \mathrm{C}$ overnight. After incubation, plasmids were isolated using the Roche High Pure Plasmid Isolation Kit (Catalogue No. 1754785).

Sequencing was performed using the ABI Prism 3700 DNA Analyzer (Applied Biosystems) automated sequencer at the Molecular Biology and Genetics Department in Istanbul Technical University. The results of sequence analysis were compared with the National Center of Biotechnology Information database using BLAST (http:// www.ncbi.nlm.nih.gov/blast/). Only sequences with high similarity $(>90 \%)$ were accepted.

\section{Results and Discussion}

\section{Geochemistry of Rock and Mine Waste Samples}

Cenozoic calc-alkaline volcanism hosts important economic deposits of industrial and metallic minerals in the study area. According to geochemical data, the $\mathrm{SiO}_{2}$ content of volcanic rocks ranges from 55.87 to $66.67 \%, \mathrm{Al}_{2} \mathrm{O}_{3}$ from 14.48 to $19.85 \%$, and $\mathrm{Fe}_{2} \mathrm{O}_{3}$ from 2.02 to $8.53 \%$ (Sanliyuksel Yucel 2013). Oxides of major elements in Can coals are dominated by $\mathrm{SiO}_{2}$ (10.7-26.83\%), $\mathrm{Al}_{2} \mathrm{O}_{3}$ (7.88-10.97\%), $\mathrm{Fe}_{2} \mathrm{O}_{3}(3.5-8.19 \%)$, and others including $\mathrm{MgO}, \mathrm{CaO}, \mathrm{NaO}_{2}, \mathrm{TiO}_{2}, \mathrm{~K}_{2} \mathrm{O}, \mathrm{P}_{2} \mathrm{O}_{5}, \mathrm{MnO}$, and $\mathrm{Cr}_{2} \mathrm{O}_{3}$, each of which comprise $<1.0 \%$ (Sanliyuksel Yucel 2013). In accordance with mineralogical components, the major oxides in coal mainly consist of clay, silica, and sulfur minerals. Total sulfur contents of coal range from 0.21 to $14.36 \mathrm{wt} \%$, and analysis of sulfur in the coal samples showed that the sulfur is mainly organic $(0.9-6.07 \%)$ pyritic (0.20-6.34\%) (Gurdal 2011). The presence of a high sulfur content in coal is attributed to the peat environment and regional volcanic activity as well as to alkaline depositional environments with intensive sulfide mineralization (Gurdal and Bozcu 2011). The concentration of arsenic (As) is associated with pyrite in coal; high As values in coals from the Can formation (maximum 6413 ppm) were previously reported by Baba et al. (2009). The average concentration of trace elements, including As, 
boron $(\mathrm{B})$, cadmium $(\mathrm{Cd})$, cobalt $(\mathrm{Co})$, copper $(\mathrm{Cu})$, manganese $(\mathrm{Mn})$, nickel $(\mathrm{Ni})$, lead $(\mathrm{Pb})$ and zinc $(\mathrm{Zn})$, were higher than the world coal average value reported by Swaine (1990) and Ketris and Yudovich (2009) and creates an ecological risk for the environment (Sanliyuksel Yucel 2013)

According to the XRD analyses, altered andesite samples include quartz, kaolinite, illite/mica, feldspar group minerals, pyrite, and clay minerals (Table 1). Pyrite crystals from andesite samples in SEM images are $<1 \mu \mathrm{m}$ and display cubic morphology (Fig. 3a). A surficial argillic alteration zone, widespread in the region, was observed on the outcrops of volcanic rocks due to the oxidation of sulfur minerals as described in previous studies (e.g., Baba and Gunduz 2010). The mineral content of coal samples contains quartz, clay group minerals, pyrite, gypsum, cristobalite, kaolinite, smectite-group minerals, and feldspar. Well-developed euhedral, authigenic pyrite crystals are shown in Fig. 3b containing $69.56 \%$ sulfur and $30.44 \%$ iron $(\mathrm{Fe})$ in EDX analysis. In addition, gypsum crystals with honeycomb form are found in coal. Total inorganic mineral contents of coal are $19 \%: 5.03 \%$ gypsum, $4.84 \%$ pyrite, $4.47 \%$ kaolinite, $3.73 \%$ quartz, and $0.93 \%$ smectite-group clay minerals (Tuncali et al. 2002). Pyrite can accelerate coal self-heating (Banerjee 2000) and in Can coals enhances the process of spontaneous combustion. Gurdal and Bozcu (2011) indicated that the majority of clay minerals in coals are probably the alteration products of volcanic material. Total sulfur content of mine wastes, which generally contain kaolinite, quartz, cristobalite, pyrite, illite/mica, opal-CT, clay group minerals, gypsum, chlorite and feldspar, in addition to jarosite and goethite, reach $5.61 \%$ in the study area (Sanliyuksel Yucel 2013). Pyrite crystals in mine wastes have cubic morphology in SEM images (Fig. 3c). Jarosite is the main secondary mineral in lake sediment (Fig. 3d) and shows a cubic morphology suggesting that it forms as a pseudomorph after pyrite (Silva et al. 2011b; Sanliyuksel Yucel and Baba 2013). Lake sediment also includes opal-CT, kaolinite, gypsum, clay-group minerals, quartz, feldspar-group minerals, zeolite, pyrite, illite/mica, and lepidocrocite (Fig. 4).

Pyrite is a common sulfur mineral in all of the investigated rocks and mine waste samples and is the main cause of acidification in the study area. Mine wastes and lake sediments contain jarosite, which further provide acidity in the lake. In addition, gypsum is a secondary mineral in mine wastes and probably occurs due to the oxidation of sulfides. Gypsum, fehydroxides, and other secondary minerals determined in the field further suggest the oxidation of sulfide minerals and acidity generation in the study area. The ability of carbonates to neutralize acid by fast reaction makes them an important part of the mineralogical assemblage for AMD prediction and prevention (Dold 2010). However, carbonate-group minerals were not determined in the research area. Only silicate minerals, which are harder to dissolve and act as a buffer when dissolved such as feldspar, kaolinite, quartz, zeolite, chlorite, and opal-CT were determined. Because these minerals dissolve slowly, they cannot effectively decrease the acid levels alone.

\section{Hydrogeochemistry of AMLs}

The result of field parameters of AMLs is summarized in Table 2. The $\mathrm{pH}$ of a solution is one of the important parameter for evaluating aquatic toxicity and the key factor in regulating sorption and leaching of metals in AMLs (Silva et al. 2011a). AMLs are characterized by low pH values ranging from 2.59 to 3.79 with a median value of 3.23 in the study area. The lowest $\mathrm{pH}$ values for all of the AMLs were obtained during a dry season with no rainfall and reduced surface and subsurface seepage. The

Table 1 XRD analyze results of rock samples, mine wastes, and lake sediment

\begin{tabular}{ll}
\hline Sample name & Explanations \\
\hline Andesite & Quartz, feldspar-group minerals, illite/mica, pyrite, clay minerals \\
& Quartz, kaolinite, pyrite, feldspar-group minerals \\
Coal & Kaolinite group minerals, quartz, mica, pyrite, gypsum, feldspar \\
& Gypsum, pyrite, kaolinite, quartz, smectite-group minerals \\
& Quartz, pyrite, kaolinite-group minerals, cristobalite, feldspar-group minerals, amorphous matter, gypsum \\
& Quartz, cristobalite, clay-group minerals, kaolinite-group minerals, pyrite, feldspar-group minerals, illite/mica, gypsum \\
Mine waste & Kaolinite, illit/mica, opal-CT, gypsum, pyrite, chlorite-group minerals, lepidocrocite, feldspar-group minerals, jarosite, \\
& goethite, quartz \\
& Jarosite, opal-CT, kaolinite, gypsum, clay-group minerals, quartz, feldspar group minerals, zeolite, pyrite, illite/mica, \\
& lepidocrocite \\
Lake sediment & Quartz, clay-group minerals, cristobalite, jarosite, feldspar-group minerals, kaolinite, illite/mica, pyrite, lepidocrocite \\
&
\end{tabular}


Fig. 3 a Pyrite crystals in altered andesite $\mathbf{b}$ cubic pyrite crystals in coal $\mathbf{c}$ cubic pyrite crystals in mine waste d pseudomorph of jarosite after pyrite in the lake sediment
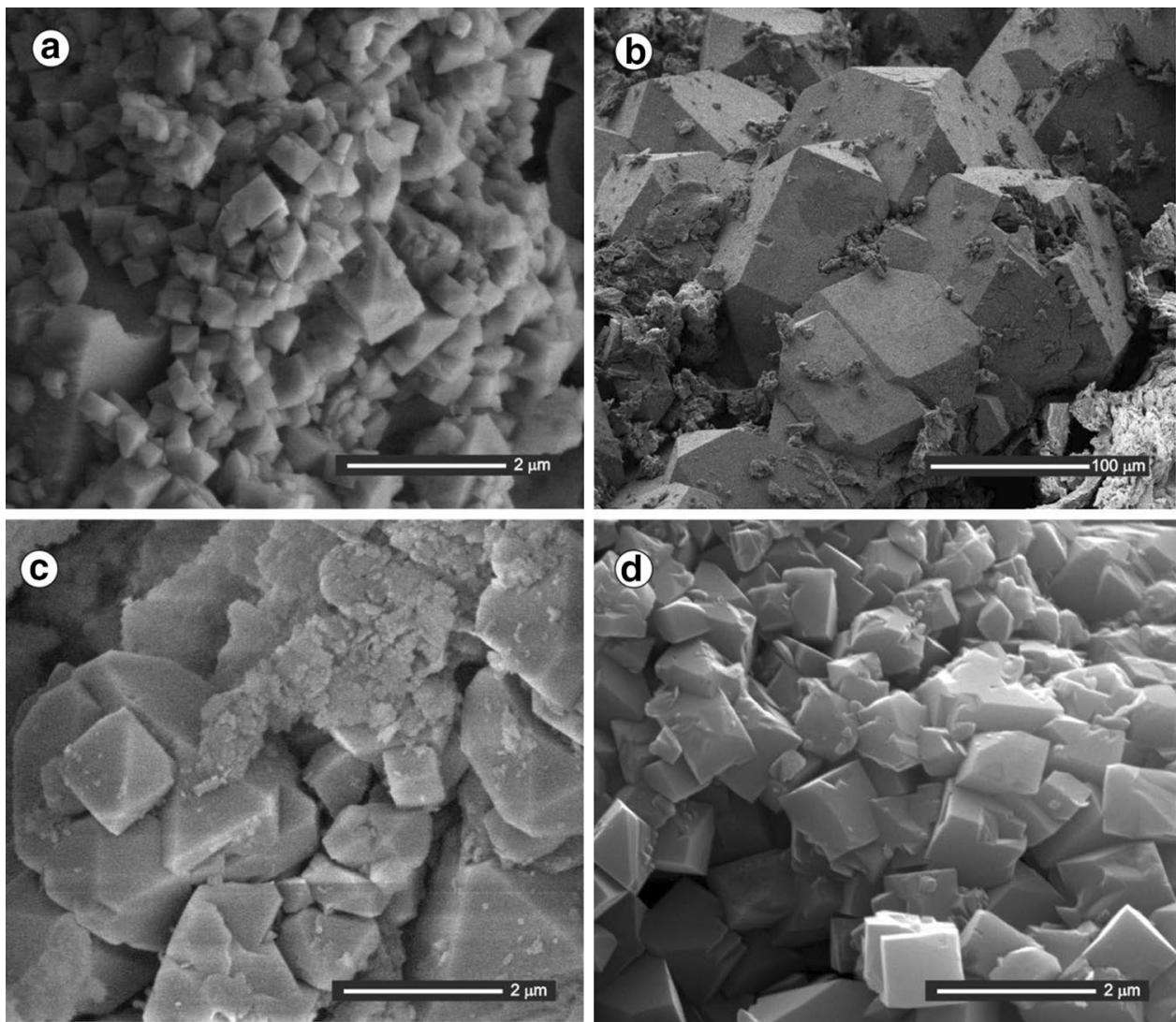

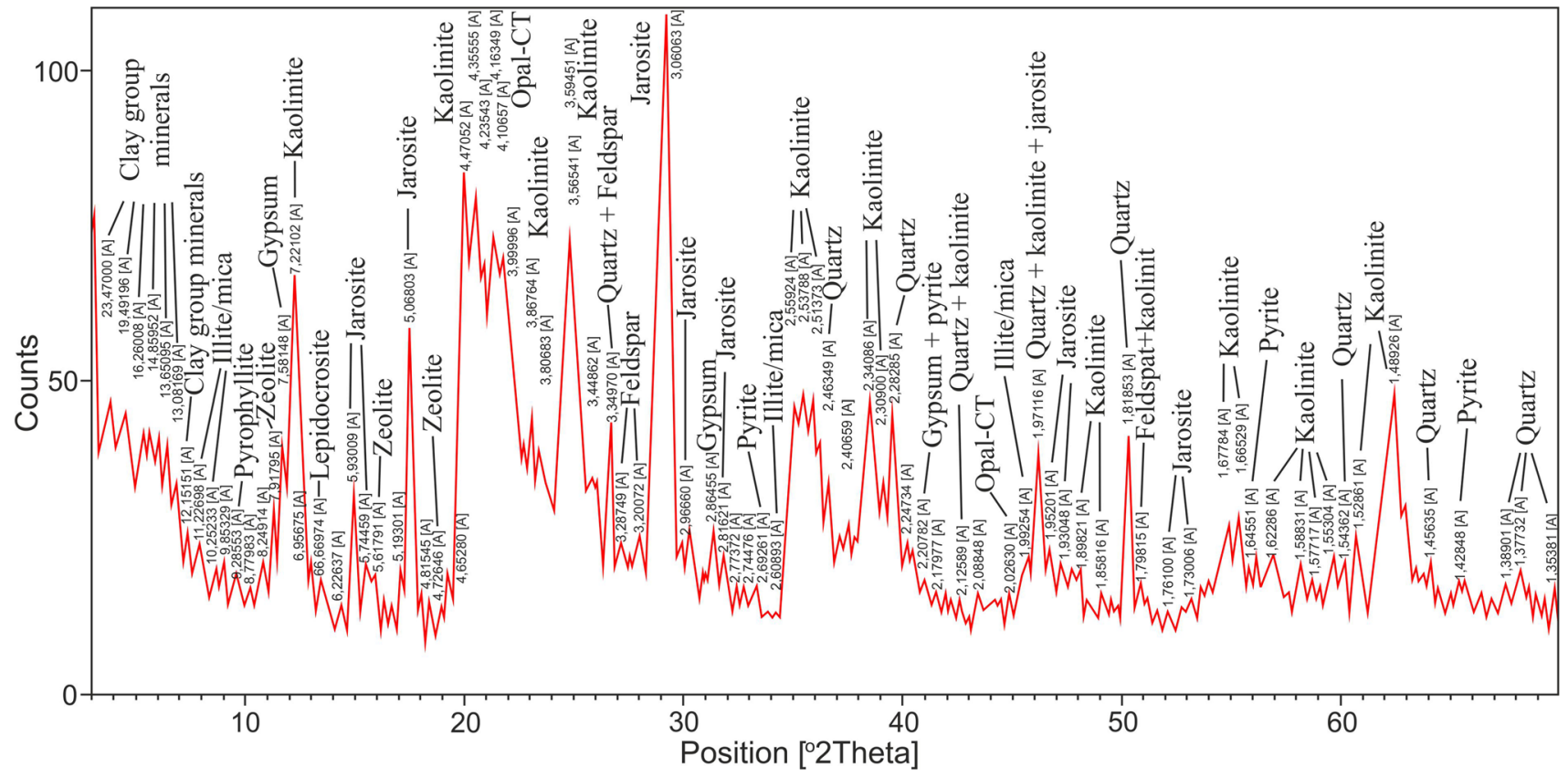

Fig. 4 XRD pattern of lake sediment

corresponding values of $\mathrm{pH}$ for March 2011, quite a rainy month, range from 3.24 to 3.79 which, in essence, is an indicator of seasonal deterioration due to reduced dilution effect. The $\mathrm{pH}$ value of rainwater was measured as 5.9 in December 2012 in the study area (Sanliyuksel Yucel 2013). In addition, Ozdilek (2013) stated that mean pH of 
Table 2 Field parameters and isotopic composition (\%) of AMLs

\begin{tabular}{|c|c|c|c|c|c|c|c|c|c|c|c|}
\hline Sample location & Sampling date & $\mathrm{pH}$ & $\begin{array}{l}\text { DO } \\
(\mathrm{mg} / \mathrm{l})\end{array}$ & $\begin{array}{l}\text { Eh } \\
(\mathrm{mV})\end{array}$ & $\begin{array}{l}\mathrm{T} \\
\left({ }^{\circ} \mathrm{C}\right)\end{array}$ & $\begin{array}{l}\mathrm{EC} \\
(\mu \mathrm{S} / \mathrm{cm})\end{array}$ & Sal (\%) & $\begin{array}{l}\text { Acidity } \\
\left(\mathrm{mgCaCO}_{3} / \mathrm{l}\right)\end{array}$ & $\delta^{18} \mathrm{O}_{\mathrm{H}_{2} \mathrm{O}}$ & $\delta^{2} \mathrm{H}_{\mathrm{H}_{2} \mathrm{O}}$ & $\delta^{3} \mathrm{H}$ \\
\hline \multirow[t]{4}{*}{ AML 1} & July 2010 & 3.05 & 5.95 & 256 & 25.6 & 4960 & 2.4 & - & - & - & - \\
\hline & March 2011 & 3.75 & - & 201 & 12.5 & 3040 & 1.4 & - & - & - & - \\
\hline & July 2011 & 2.95 & - & 256 & 27.3 & 4180 & 2.2 & 1090 & -0.08 & -12.15 & 10.4 \\
\hline & March 2012 & 2.59 & - & 235 & 9.1 & 4320 & 2.2 & 805 & -1.65 & -21.49 & 6.23 \\
\hline \multirow[t]{4}{*}{ AML 2} & July 2010 & 3.09 & 4 & 255 & 26.7 & 6430 & 3.5 & - & - & - & - \\
\hline & March 2011 & 3.24 & - & 228 & 9.5 & 5550 & 2.9 & - & - & - & - \\
\hline & July 2011 & 2.91 & - & 260 & 28.9 & 5440 & 2.9 & 1245 & -2.32 & -24.78 & 7.76 \\
\hline & March 2012 & 2.74 & - & 233 & 10 & 5820 & 1.4 & 870 & -4.14 & -33.13 & 6.04 \\
\hline \multirow[t]{4}{*}{ AML 3} & July 2010 & 3.12 & 4.2 & 257 & 28.7 & 2990 & 1.5 & - & - & - & - \\
\hline & March 2011 & 3.26 & - & 227 & 11.1 & 3080 & 1.5 & - & - & - & - \\
\hline & July 2011 & 3 & - & 254 & 28.2 & 2990 & 1.5 & 840 & -2.82 & -26.87 & 9.21 \\
\hline & March 2012 & 2.92 & - & 221 & 7.6 & 3380 & 1.6 & 580 & -3.91 & -33.32 & 7.03 \\
\hline \multirow[t]{4}{*}{ AML 4} & July 2010 & 3.6 & 6.1 & 230 & 30.6 & 3180 & 1.6 & - & - & - & - \\
\hline & March 2011 & 3.71 & - & 201 & 11.8 & 3240 & 1.5 & - & - & - & - \\
\hline & July 2011 & 3.46 & - & 227 & 26.7 & 3070 & 1.5 & 330 & -3.64 & -30.63 & 8.04 \\
\hline & March 2012 & 3.32 & - & 198 & 8.2 & 3240 & 1.6 & 170 & -4.74 & -35.81 & 6.53 \\
\hline \multirow[t]{4}{*}{ AML 5} & July 2010 & 3.22 & 6.45 & 254 & 30.5 & 3070 & 1.5 & - & - & - & - \\
\hline & March 2011 & 3.79 & - & 198 & 11.7 & 1345 & 0.5 & - & - & - & - \\
\hline & July 2011 & 3.2 & - & 242 & 25.4 & 2050 & 0.9 & 510 & -5.67 & -40.24 & 9.92 \\
\hline & March 2012 & 3.7 & - & 177 & 8.5 & 1040 & 0.4 & 460 & -7.73 & -47.23 & 5.71 \\
\hline \multirow[t]{2}{*}{ Rain } & May 2012 & - & - & - & - & - & - & - & -5.91 & -38.29 & - \\
\hline & December 2012 & 5.9 & - & - & - & - & - & - & -4.96 & -25.06 & - \\
\hline Snow & March 2012 & - & - & - & - & - & - & - & -9.84 & -58.24 & 8.62 \\
\hline \multicolumn{12}{|l|}{$\begin{array}{l}\text { Depth }(\mathrm{m}) \text { AML } 2 \\
\text { (median values) }\end{array}$} \\
\hline 0.1 & July 2010 & 3.08 & 3.8 & 254 & 26.5 & 6420 & 3.5 & - & - & - & - \\
\hline 3 & & 3.16 & 3.4 & 224 & 21.6 & 6610 & 3.6 & - & - & - & - \\
\hline 6 & & 3.28 & 3.3 & 192 & 17 & 6820 & 3.8 & - & - & - & - \\
\hline 9 & & 3.52 & 2.3 & 175.5 & 13.3 & 6902 & 3.85 & - & - & - & - \\
\hline 12 & & 3.84 & 1.2 & 167.5 & 12.95 & 6980 & 4 & - & - & - & - \\
\hline Maximum & & 3.85 & 4 & 255 & 26.8 & 6980 & 4 & - & - & - & - \\
\hline Minimum & & 3.04 & 1.06 & 167 & 12.9 & 6380 & 3.3 & - & - & - & - \\
\hline SD & & 0.19 & 2.14 & 30.54 & 4.87 & 195.28 & 0.17 & - & - & - & - \\
\hline
\end{tabular}

rain water in the Canakkale region was 6.56 between 2010 and 2013. Mine wastes, which contains pyrite minerals from sedimentary and volcanic rocks, cover $1.66 \mathrm{~km}^{2}$ in the study area (Sanliyuksel Yucel et al. 2014) and affects water sources (e.g., creeks, mine lakes). Sanliyuksel Yucel and Baba (2013) stated that $\mathrm{pH}$ values of the AMLs' surrounding creeks were between 2.85 and 5.75. The $\mathrm{pH}$ values of all of the AMLs vary over a narrow range, typically with low $\mathrm{pH}$, was attributed to sulfide oxidation primarily of pyrite and low bicarbonate buffering capacity similar to their counterparts in the rest of the world (Friese et al. 1998; Bachmann et al. 2001). Because low $\mathrm{pH}$ enhances the mobility of most elements in mine wastes, the EC level of all AMLs were found to be in the high range. High EC values with a maximum of $6430 \mu \mathrm{S} / \mathrm{cm}$ were measured in AML 2, and the lowest EC value $(1040 \mu \mathrm{S} / \mathrm{cm})$ was measured in AML 5, which compared well with the age of the lakes. Acidity values of AMLs range from 170 to $1245 \mathrm{mgCaCO}_{3} / 1$. Eh values of AMLs ranged from 177 to $260 \mathrm{mV}$, and lower values generally correspond to March sampling periods, which can be attributed to the $\mathrm{Fe}^{2+} / \mathrm{Fe}^{3+}$ redox couple as well as Mn because variations in $\mathrm{Fe}$ (II) and $\mathrm{Mn}$ concentration compared well with March samplings. Temperature values of AMLs change with season, time of day, and depth of the water body. 
Iron and aluminum $(\mathrm{Al})$ are the most predominant metal species in the AMLs. High $\mathrm{Al}$ concentrations in acidic waters result from the weathering of aluminosilicate minerals such as clays, altered volcanic rocks and coals, which are dominant in the area. In water samples from the oldest AML 2, the maximum Al concentration of $360.6 \mathrm{mg} / \mathrm{l}$ was detected (Table 3). In general, Al concentration of all of the lakes was high and increased together with the age of the lakes reaching highest levels in the oldest lakes (AMLs 2,3 , and 1 , with respect to age) and lowest levels in the youngest lakes (AMLs 5 and 4). As shown in Table 3, the other dissolved major constituents (sodium [Na], potassium $[\mathrm{K}]$, calcium $[\mathrm{Ca}]$, magnesium $[\mathrm{Mg}]$, and $\mathrm{Fe}$ ) were also correlated considerably with the age of the lakes. The highest concentration of $\mathrm{Ca}, \mathrm{Mg}$, and $\mathrm{Na}$ with $\mathrm{Mn}, \mathrm{Fe}$, and $\mathrm{Zn}$ was determined in the oldest lake AML 2, thus indicating that water-rock interaction may release metals into lakes. Due to the fact that AML 3 drained into Katran Creek in 2009, $\mathrm{SO}_{4}, \mathrm{Mg}, \mathrm{K}, \mathrm{Na}$, and $\mathrm{Mn}$ concentrations, except for $\mathrm{Al}$, were significantly lower compared with AMLs 4 and 5 in the July 2010 and March 2011 sampling periods.

Calcium values ranged from 85.47 to $520.1 \mathrm{mg} / \mathrm{l}$ with an average value of $318.8 \mathrm{mg} / \mathrm{l}$ and were highest in the oldest lakes. $\mathrm{Mg}$ values ranged from 28.74 to $357.8 \mathrm{mg} / \mathrm{l}$. The leaching of $\mathrm{Ca}$ and $\mathrm{Mg}$ can be assumed to be controlled by the dissolution of $\mathrm{Ca}$ and $\mathrm{Mg}$-bearing silicates and gypsum (Rigol et al. 2009; Silva et al. 2011a). Iron concentrations of AMLs ranged between 7.7 and $329.7 \mathrm{mg} / \mathrm{l}$. The greater Fe concentrations and $\mathrm{Fe}(\mathrm{III}) / \mathrm{Fe}$ (II) ratios were measured in the dry season for all of the lakes indicating the influence of evaporation on water chemistry as well as oxygenic conditions in the lakes. The $\mathrm{pH}$ values of all AMLs were close to 3 indicating that chemical oxidation of $\mathrm{Fe}(\mathrm{II})$ to $\mathrm{Fe}(\mathrm{III})$ is favored. Consistent with this, the dominant form of Fe was found to be $\mathrm{Fe}$ (III) in all lakes (see Table 3) as with most other AMLs. High Fe levels are amongst the typical characteristics of pyrite oxidation. Compared with common ions of $\mathrm{Na}^{+}, \mathrm{K}^{+}$and $\mathrm{Cl}^{-}, \mathrm{Fe}(\mathrm{II})$ in AMLs indicates greater oxidation of pyrite relative to chemical precipitation of Fe(III) oxyhydroxy-sulfates (e.g., jarosite) in the lakes.

Sulfate was consistently the predominant anion in all lake samples as is the case in many other acidic waters worldwide (Nordstrom et al. 2000; Espana et al. 2008). The concentration of sulfate ranged between 595 and $5370 \mathrm{mg} / \mathrm{l}$ with a median value of $2140 \mathrm{mg} / \mathrm{l}$ (see Table 3 ). The highest values were measured in the more acidic AML 2. The good correlation between sulfate and $\mathrm{Ca}$ in all chemical analysis results of the lakes $\left(r^{2}=0.84\right)$ suggests that the dissolution of gypsum is also a source of sulfate.

$\mathrm{Mn}, \mathrm{Zn}$, and $\mathrm{Ni}$ were the main dissolved metals in the AMLs with maximum values of $225.6,15.7$, and $2.43 \mathrm{mg} / \mathrm{l}$, respectively, and these values were measured in the more acidic water of AML 2. The concentrations of these metals in acidic waters may be controlled by the rate of weathering and dissolution of source minerals or perhaps by adsorption or coprecipitation with other phases, such as jarosite, that were determined in the field. The dominant dissolved metals in AMLs, in order of average abundance, are $\mathrm{Al}>\mathrm{Fe}>\mathrm{Mn}>\mathrm{Zn}>\mathrm{Ni}$. $\mathrm{Al}, \mathrm{Fe}, \mathrm{SO}_{4}, \mathrm{Mn}, \mathrm{Ni}$, and $\mathrm{Zn}$ concentrations of all lakes greatly exceeded the limits for national and international water-quality criteria (ITASHY 2005; United States Environmental Protection Agency 2012; World Health Association 2011). Seasonal variations in precipitation may affect the transport characteristics of the process by water flow. The element composition of lake water and local geology correlates with the geologic makeup of the study area. Overall, all water characteristics of AMLs compared well with their counterparts around the world (Pietsch 1979; Friese et al. 1998; Kwong and Lawrence 1998; Bachmann et al. 2001; Karakas et al. 2003; Espana et al. 2008) and resemble the poor water-quality pattern that is mostly driven by sulfur oxidation in the region.

\section{Water Column and Sediments of AML 2}

Morphological and some hydrochemical properties of AML 2 were studied in detail. During the course of field work, no major outflow from the lake was detected. The depth measurements of across the longest part of the lake $\left(A-A^{\prime}\right)$ had a range of $1.46-13.45 \mathrm{~m}$, and the average depth was calculated to be $7.41 \mathrm{~m}$. According to the bathymetry map given in Fig. 5, the deepest point in the lake corresponded to measurement point 9_5, which was situated approximately on the lake centerline (Fig. 6). The deepest area of the lake corresponded to the main coal vein where major extraction activities were performed during the operation phase. The bathymetry map was then used to compute the perimeter as $616 \mathrm{~m}$ and the surface area as $15,550 \mathrm{~m}^{2}$ on July 18, 2010.

The results of field parameters (i.e., temperature, $\mathrm{pH}$, DO, electrical conductivity, oxidation reduction potential, and salinity) are presented in Table 2 and Fig. 7. Each measurement is presented along with SD values (see Table 2). Based on these results, AML 2 showed typical characteristics of an AML consistent with the other AMLs in the study area. In July 2010, slight chemical and/or physical layering was present at a depth of $6 \mathrm{~m}$. In general, $\mathrm{pH}$ was found to be lower on the surface and increased with increasing depth as shown in the depth profile of $\mathrm{pH}$ measurements from all sampling locations. The lowest $\mathrm{pH}$ value (i.e., 3.04) was measured at a surface sampling station (location 11,11_1) and the highest $\mathrm{pH}$ (i.e., 3.85) at the second deepest point of the lake (i.e., $12.4 \mathrm{~m}$ at point 10_5). The average $\mathrm{pH}$ in the surface layer of AML 2 was 
Table 3 Solute concentrations of AMLs (mg/l)

\begin{tabular}{|c|c|c|c|c|c|c|c|c|c|}
\hline Sample location & Sampling date & $\mathrm{Al}$ & $\mathrm{Ca}$ & $\mathrm{Fe}(\mathrm{t})$ & $\mathrm{Fe}(\mathrm{II})$ & $\mathrm{Fe}(\mathrm{III})$ & $\mathrm{K}$ & $\mathrm{Mg}$ & $\mathrm{Mn}$ \\
\hline \multirow[t]{4}{*}{ AML 1} & July 2010 & 247.90 & 377.70 & 90.30 & - & - & 0.99 & 230.50 & 67.70 \\
\hline & March 2011 & 252.60 & 350.70 & 83.70 & - & - & 1.90 & 178.10 & 72.40 \\
\hline & July 2011 & 286.60 & 478.10 & 91.90 & 7.40 & 84.50 & 1.60 & 228.90 & 83.90 \\
\hline & March 2012 & 219.60 & 356.10 & 54.20 & 7.40 & 46.80 & 0.95 & 182.00 & 66.48 \\
\hline \multirow[t]{4}{*}{ AML 2} & July 2010 & 345.80 & 477.70 & 328.30 & - & - & 0.99 & 230.50 & 217.90 \\
\hline & March 2011 & 327.50 & 450.70 & 227.20 & - & - & 1.90 & 278.10 & 225.60 \\
\hline & July 2011 & 360.60 & 520.10 & 329.70 & 8.90 & 320.80 & 2 & 357.80 & 187.10 \\
\hline & March 2012 & 308.80 & 461.90 & 154.60 & 36.50 & 118.10 & 2 & 306.00 & 182.20 \\
\hline \multirow[t]{4}{*}{ AML 3} & July 2010 & 118.70 & 98.51 & 27.70 & - & - & 3.36 & 63.25 & 24.10 \\
\hline & March 2011 & 124.80 & 147.30 & 28.70 & - & - & 2.09 & 98.53 & 25.60 \\
\hline & July 2011 & 129.50 & 229.00 & 34.30 & 3.60 & 30.70 & 4.80 & 80.60 & 27.50 \\
\hline & March 2012 & 155.80 & 245.10 & 21.50 & 12.60 & 8.90 & 2.00 & 92 & 33.80 \\
\hline \multirow[t]{3}{*}{ AML 4} & March 2011 & 20.60 & 386.50 & 9.60 & - & - & 9.94 & 125.40 & 35.50 \\
\hline & July 2011 & 16.80 & 411.30 & 7.70 & 1.30 & 6.40 & 15.80 & 119.40 & 32.70 \\
\hline & March 2012 & 18.20 & 368.80 & 9.80 & 4.60 & 5.20 & 12 & 118.00 & 32.50 \\
\hline \multirow[t]{3}{*}{ AML 5} & March 2011 & 36.80 & 122.10 & 15.60 & - & - & 9.10 & 49.67 & 12.20 \\
\hline & July 2011 & 62.80 & 172.10 & 25.30 & 1.80 & 23.50 & 12.41 & 62.61 & 19.90 \\
\hline & March 2012 & 18.10 & 85.47 & 12.30 & 10.70 & 1.60 & 4.78 & 28.74 & 9.80 \\
\hline \multicolumn{10}{|l|}{$\begin{array}{l}\text { Depth (m)- AML } 2 \\
\text { (median values) }\end{array}$} \\
\hline 0.1 & July 2010 & 344.63 & 495.18 & 327.48 & - & - & 0.97 & 226.18 & 217.75 \\
\hline 3 & & 338.16 & 479.75 & 324.13 & - & - & 1.07 & 218.83 & 193.45 \\
\hline 6 & & 332.42 & 464.48 & 341.78 & - & - & 0.94 & 219.44 & 180.2 \\
\hline 9 & & 316.26 & 450.42 & 420.68 & - & - & 3.89 & 215.69 & 181.67 \\
\hline 12 & & 308.46 & 466.87 & 481.83 & - & - & 11.86 & 227.15 & 182.49 \\
\hline Maximum & & 345.15 & 516.38 & 481.83 & - & - & 11.86 & 241.36 & 219.64 \\
\hline Minimum & & 308.46 & 439.52 & 322.59 & - & - & 0.94 & 205.46 & 179.18 \\
\hline SD & & 11002.3 & 19.98 & 42137.56 & - & - & 2.37 & 9.42 & 16276.51 \\
\hline Sample location & Sampling date & $\mathrm{Na}$ & $\mathrm{Ni}$ & $\mathrm{Zn}$ & & $\mathrm{Cl}$ & $\mathrm{SO}_{4}$ & TDS & $\mathrm{EstSO}_{4}^{\mathrm{a}}$ \\
\hline \multirow[t]{4}{*}{ AML 1} & July 2010 & 104.80 & 0.52 & 2.80 & & 78 & 3512 & 1289 & 3867 \\
\hline & March 2011 & 115.92 & 1.07 & 4.40 & & 73 & 3017 & 1440 & 4320 \\
\hline & July 2011 & 108.80 & 1.07 & 4.88 & & 63 & 3000 & 1226 & 3678 \\
\hline & March 2012 & 77.01 & 0.57 & 2.75 & & 46 & 3015 & 985 & 2955 \\
\hline \multirow[t]{4}{*}{ AML 2} & July 2010 & 164.27 & 2.43 & 15.48 & & 78.30 & 5012 & 1994 & 5982 \\
\hline & March 2011 & 176.93 & 1.80 & 15.70 & & 73 & 5017 & 1851 & 5553 \\
\hline & July 2011 & 168.30 & 2.36 & 12.03 & & 143 & 4600 & 1832 & 5496 \\
\hline & March 2012 & 157.97 & 2.02 & 10.28 & & 97 & 5370 & 1750 & 5250 \\
\hline \multirow[t]{4}{*}{ AML 3} & July 2010 & 53.20 & 0.57 & 2.37 & & 39.80 & 903 & 477 & 1431 \\
\hline & March 2011 & 76.93 & 0.60 & 1.89 & & 38.75 & 988 & 589 & 1767 \\
\hline & July 2011 & 98.60 & 0.60 & 1.23 & & 69 & 1500 & 610 & 1830 \\
\hline & March 2012 & 108.52 & 0.60 & 3.92 & & 67 & 2520 & 812 & 2436 \\
\hline \multirow[t]{3}{*}{ AML 4} & March 2011 & 216.15 & 0.40 & 1.70 & & 99.41 & 1018 & 505 & 1515 \\
\hline & July 2011 & 265.70 & 0.42 & 1.54 & & 106 & 1700 & 614 & 1842 \\
\hline & March 2012 & 243.13 & 0.22 & 0.60 & & 100 & 1760 & 677 & 2031 \\
\hline \multirow[t]{3}{*}{ AML 5} & March 2011 & 44.39 & 0.10 & 0.96 & & 104.56 & 895 & 295 & 885 \\
\hline & July 2011 & 81.21 & 0.18 & 1.23 & & 72 & 1000 & 393 & 1179 \\
\hline & March 2012 & 43.97 & 0.10 & 0.43 & & 54 & 594 & 173 & 519 \\
\hline
\end{tabular}


Table 3 continued

\begin{tabular}{|c|c|c|c|c|c|c|c|c|}
\hline Sample location & Sampling date & $\mathrm{Na}$ & $\mathrm{Ni}$ & $\mathrm{Zn}$ & $\mathrm{Cl}$ & $\mathrm{SO}_{4}$ & TDS & EstSO $_{4}^{\mathrm{a}}$ \\
\hline \multicolumn{9}{|c|}{$\begin{array}{l}\text { Depth (m)- AML } 2 \\
\text { (median values) }\end{array}$} \\
\hline 0.1 & July 2010 & 164 & 2.31 & 15.05 & 79.67 & 5081.5 & - & - \\
\hline 3 & & 162.25 & 2.21 & 14.46 & 76.74 & 4829.5 & - & - \\
\hline 6 & & 163.33 & 2.16 & 14.01 & 74.96 & 4681.5 & - & - \\
\hline 9 & & 169.96 & 2.24 & 14.49 & 77.49 & 4767 & - & - \\
\hline 12 & & 181.65 & 2.26 & 15.16 & 76.13 & 4924 & - & - \\
\hline Maximum & & 181.65 & 2.41 & 15.16 & 85.69 & 5305 & - & - \\
\hline Minimum & & 159.25 & 2.14 & 13.85 & 77.57 & 4890 & - & - \\
\hline SD & & 4.87 & 79.66 & 444.63 & 4.13 & 205.68 & - & - \\
\hline
\end{tabular}

${ }^{a}$ Estimated $\mathrm{SO}_{4}$ concentration calculated by using TDS concentration $(\mathrm{TDS} \mathrm{mg} / \mathrm{l} \times 3)=\mathrm{SO}_{4}$

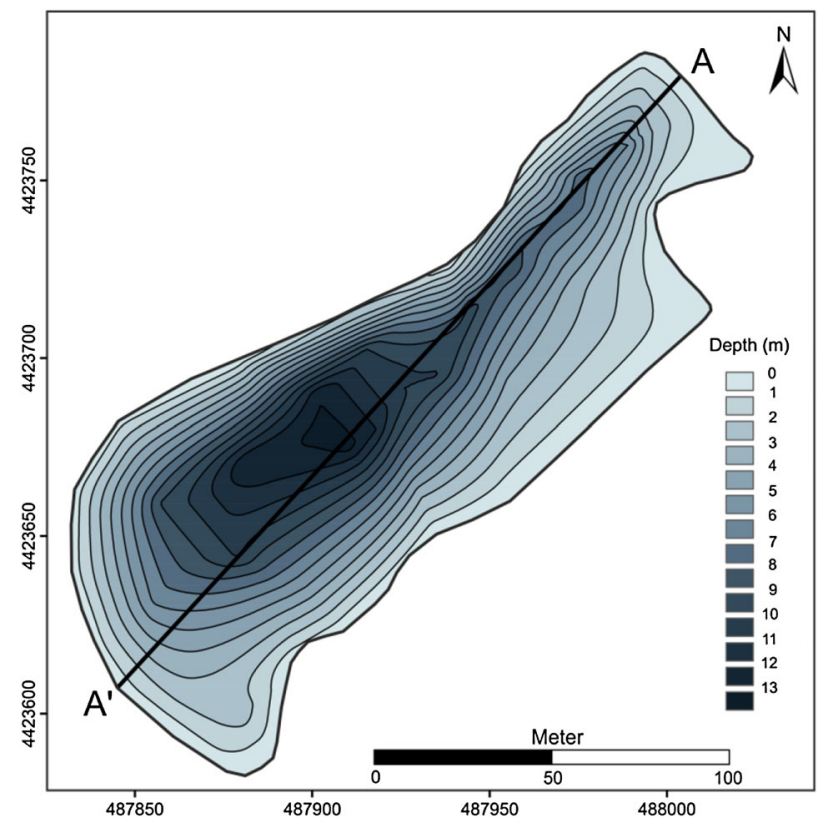

Fig. 5 Bathymetric map of AML 2 during July 2010 (Sanliyuksel Yucel and Baba 2013)
3.07. The amount of DO values ranged from 1.1 to $4 \mathrm{mg} / \mathrm{l}$ with an average of $3.28 \mathrm{mg} / \mathrm{l}$. It was found that DO levels decreased as a function of depth as shown in Fig. 7, and the lowest layers of the lake had DO levels of approximately $1 \mathrm{mg} / \mathrm{l}$ (location 9, 9_5). Eh values are typically found to be high at the surface of the lake in all samples. Eh values ranged from 167 to $257 \mathrm{mV}$ representing oxidizing conditions throughout the water column. There was a significant indication of a stratified pattern in the lake with a gradient exceeding $100 \mathrm{mV}$, which is similar to temperature $\left(14{ }^{\circ} \mathrm{C}\right)$. Temperature values ranged from 12.9 to $26.8{ }^{\circ} \mathrm{C}$ with values decreasing as a function of increasing depth. EC values ranged between 6390 and $6990 \mu \mathrm{S} / \mathrm{cm}$ with an average value of $6652 \mu \mathrm{S} / \mathrm{cm}$. The vertical profile of EC values increased with increasing depth, and this is more pronounced at a depth of $6 \mathrm{~m}$. The highest $\mathrm{EC}$ value was measured as $6990 \mu \mathrm{S} / \mathrm{cm}$ at a depth of $12 \mathrm{~m}$ (i.e., location 9,9_5) close to the water-sediment interface where extensive dissolution reactions would be expected, and increased salinity values are consistent with this

Fig. 6 Vertical profile of AML 2 (interval $15 \mathrm{~m}$ )

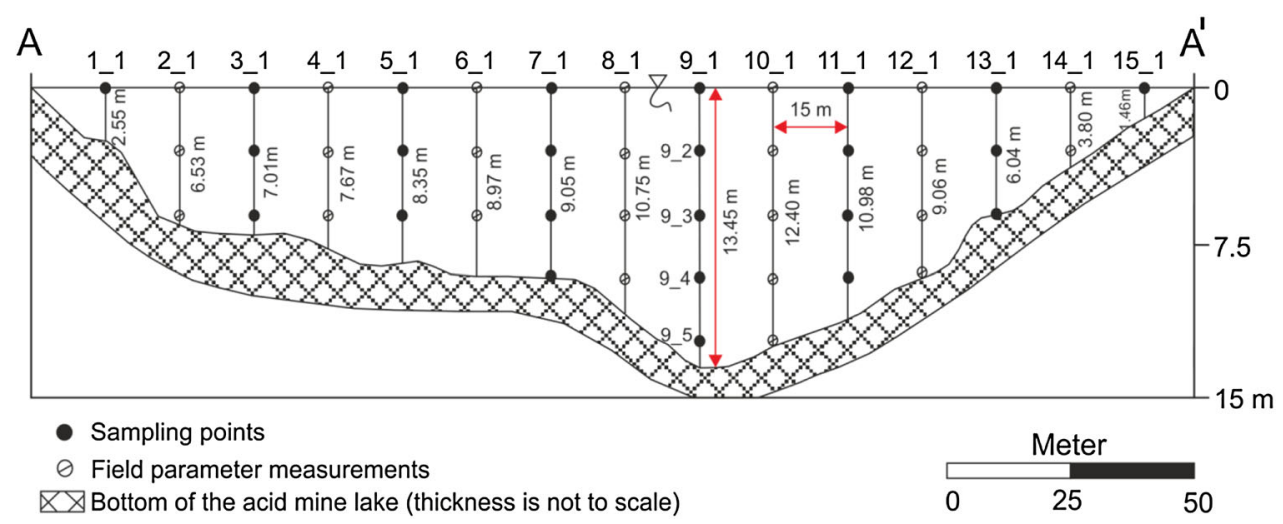


Fig. 7 Vertical profiles of field parameters of AML 2
pH
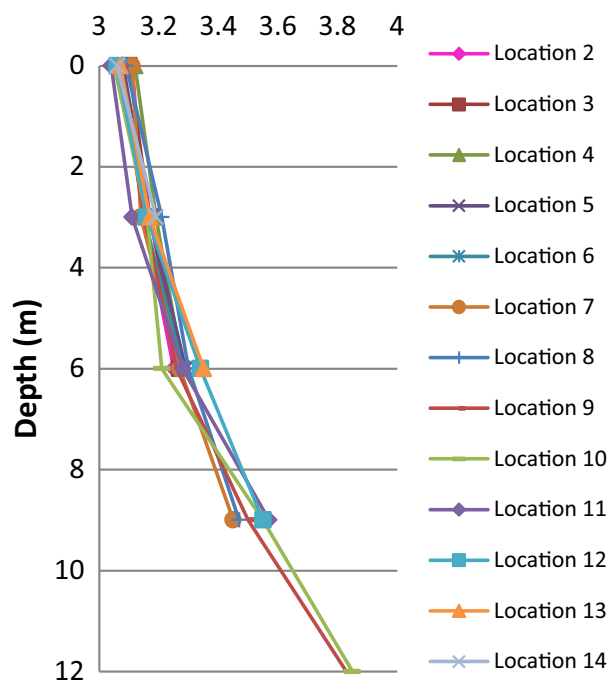

$\mathrm{EC}(\mu \mathrm{S} / \mathrm{cm})$
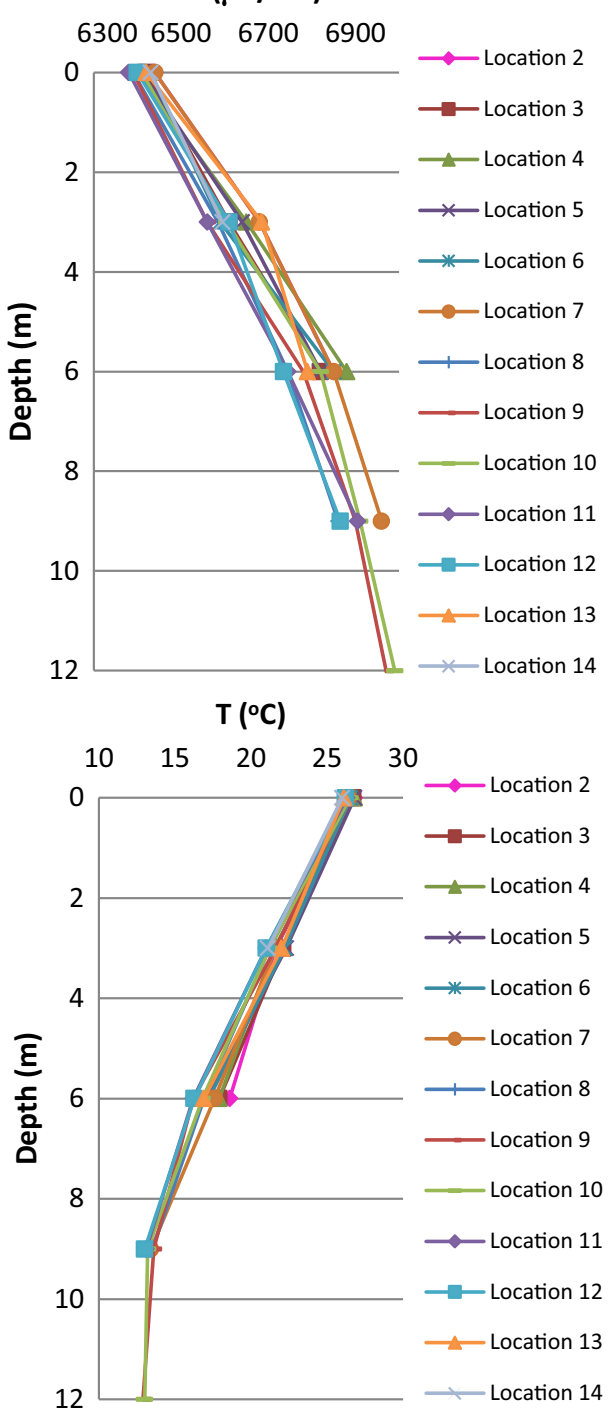

Eh (mV)

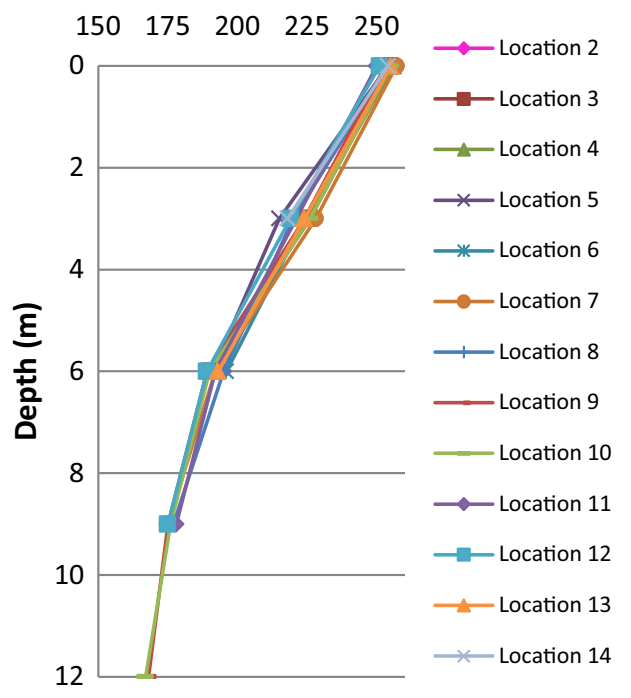

DO (mg/l)

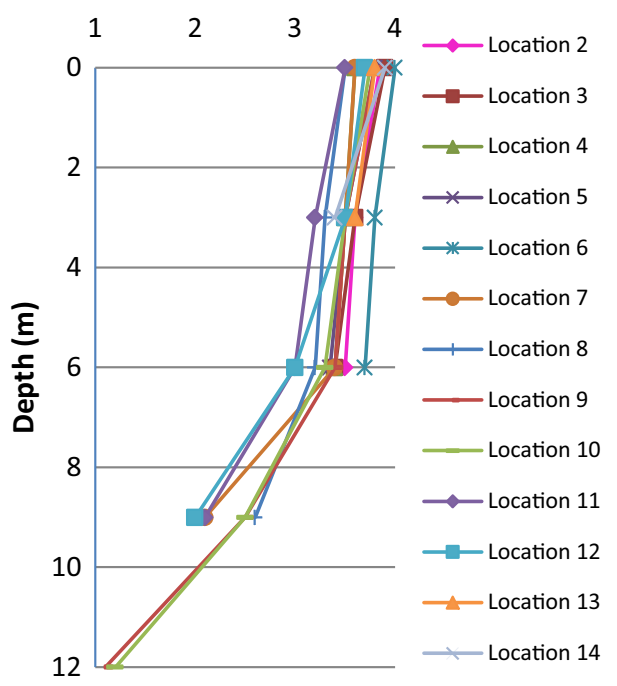


determination. Salinity values increase with increasing depth, and the median value is $3.8 \%$.

Sulfate, the predominant anion, in surface water ranged from 4916 to $5305 \mathrm{mg} / \mathrm{l}$ decreasing to $4632 \mathrm{mg} / \mathrm{l}$ at $6-\mathrm{m}$ depth with later increasing to $4924 \mathrm{mg} / \mathrm{l}$ at the deepest part of the lake (Fig. 8). A good agreement between estimated sulfate and the actual measurements were determined in young lakes (AMLs 5 and 4) unlike old lakes (AMLs 2 and 1) (see Table 3); this can be attributed to different sulfur species in the lakes. For example, enhanced pyrite oxidation and production of solid elemental sulfur, as evidenced by higher sulfate concentration in the oldest lakes, may cause sulfur imbalance (Balci et al. 2007). It is also possible that the precipitation of $\mathrm{Fe}(\mathrm{III})$ sulfate minerals (e.g., jarosite) in Fe-rich lakes (AMLs 1 and 2) may cause this discrepancy in sulfur budget and emphasizes different $\mathrm{S}$ and Fe chemistry in the lakes. The lowest sulfate concentration for all of the sampling points was determined at a 6-m depth. The increasing sulfate trend after 6-m depth can be related to the dissolution of sulfate-bearing minerals, such as jarosite, determined in the lake sediment.

$\mathrm{Ca}$ and $\mathrm{Mg}$ cations were detected at high levels in the lake water similar to the other AMLs in the study area. The $\mathrm{Ca}$ level ranged from 439.52 to $516.38 \mathrm{mg} / \mathrm{l}$ with an average value of $477.08 \mathrm{mg} / \mathrm{l} . \mathrm{Mg}$ values ranged from 205.46 to $241.36 \mathrm{mg} / \mathrm{l}$. Consistent with $\mathrm{Mg}$, Ca also did not show significant differences between surface and deeper layers (see Fig. 8). High concentration of elements (e.g., $11.86 \mathrm{mg} / \mathrm{l}$ of $\mathrm{K}, 181.65 \mathrm{mg} / \mathrm{l}$ of $\mathrm{Na}, 2.41 \mathrm{mg} / \mathrm{l}$ of $\mathrm{Ni}$, and $15.16 \mathrm{mg} / \mathrm{l}$ of $\mathrm{Zn}$ ) were measured in the deepest part of the lake at all of the sampling points. Significant increases in the concentration of $\mathrm{K}$ and $\mathrm{Fe}(\mathrm{t})$ with depth (i.e., at $6 \mathrm{~m}$ ) are also consistent with the dissolution of jarosite. The total $\mathrm{Fe}$ concentration increased consistently throughout the profile, ranging from 322.59 to $481.83 \mathrm{mg} / \mathrm{l}$, and was more pronounced at 6-m depth as $417.2 \mathrm{mg} / \mathrm{l}$.

High Al concentration of $345.15 \mathrm{mg} / \mathrm{l}$ was measured at the location point 3_1, which was in surface water, whereas the minimum value was recorded as $308.46 \mathrm{mg} / \mathrm{l}$ in the deepest part of the lake (12 m, location 9_5). In general, the $\mathrm{Al}$ concentration decreased as a function of depth in the lake (Fig. 9). The slight increase in $\mathrm{pH}$ with depth could be the main reason for lower levels $\mathrm{Al}$ in the deeper part of the lake. The major sources of $\mathrm{Al}$ in the lake are clay minerals and altered volcanic rocks. Lake water had extremely high Mn concentrations, which ranged from 179.18 to $219.64 \mathrm{mg} / \mathrm{l}$ with a median value of $192.5 \mathrm{mg} / \mathrm{l}$. Significant changes in $\mathrm{Mn}$ concentration were not determined along the vertical profile. Maximum and minimum $\mathrm{Ni}$ concentrations were measured as 2.41 and $2.14 \mathrm{mg} / \mathrm{l}$, respectively. Nickel concentration showed decreasing trend until 6-m depth followed by an increasing trend at location 9_5. The depth profile of $\mathrm{Zn}$ levels in the lake also showed a similar pattern to that of Ni. Changes in concentration of $\mathrm{Zn}$ and $\mathrm{Ni}$ as a function of depth, consistent with depth profile of $\mathrm{Fe}$, may indicate the role of adsorption or coprecipitation of these minerals with Fe-oxides in addition to clay minerals determined in the lakes. The dissolved levels of metals are primarily associated with their corresponding levels in coal and volcanic rocks.

The XRD profile of the sediments show detrital minerals (e.g., quartz, feldspar, illite/mica), which are common in volcanic rocks outcropping in the area, in addition to secondary alteration minerals such as jarosite, gypsum, lepidocrocite, and kaolinite (see Table 1). A higher presence of jarosite was observed in surface sediments along the shoreline of the lake. A detailed microscopic investigation with SEM/EDX also showed the presence of pseudomorph jarosite crystals (see Fig. 3d) and pyrite in the lake sediments. The presence of sulfates (e.g., gypsum) in the lake sediments was also documented by XRD. The presence of schwertmannite, commonly found in acidic and iron- and sulfate-rich environments, was not confirmed by XRD probably due to its low crystallinity relative to detrital materials or its transformation to goethite with time (Bingham et al. 1996; Cornell and Schwertmann 2003; Jönsson et al. 2005, 2006).

\section{Isotope Geochemistry of AMLs}

The $\delta^{18} \mathrm{O}_{\mathrm{H}_{2} \mathrm{O}}$ and $\delta^{2} \mathrm{H}_{\mathrm{H}_{2} \mathrm{O}}$ values for all field samples (lake water, rain, and snow) collected in this study are presented in Table 2. Lake water samples had $\delta^{18} \mathrm{O}$ values ranging from -0.08 to $-7.73 \%$ and $\delta^{2} \mathrm{H}$ values ranged from -12.15 to $-47.23 \%$. Sanliyuksel Yucel (2013) stated that the $\delta^{18} \mathrm{O}$ values of groundwater obtained from observation wells (OW1, 2, and 3) near the study area ranged from -6.72 to $-8.47 \%$, and $\delta^{2} \mathrm{H}$ values ranged from -1.35 to $-0.05 \%$. For rain water sampled in December and May 2012 , the $\delta^{18} \mathrm{O}$ value was -4.96 to $-5.91 \%$, and that of $\delta^{2} \mathrm{H}$ was -25.06 to $-38.29 \%$, respectively. $\delta^{18} \mathrm{O}$ and $\delta^{2} \mathrm{H}$ values of the snow sample were -9.84 and $-58.24 \%$, respectively.

The highest $\delta^{18} \mathrm{O}$ and $\delta^{2} \mathrm{H}$ values were observed for AML 1 water and were attributed to the evaporation of lake water. In general, enrichment in both $\delta^{18} \mathrm{O}$ and $\delta^{2} \mathrm{H}$ were obtained in water samples collected in the summer. Figure 10 plots the isotopic composition of all of the waters sampled compared with the local meteoric water line. The lake water does not plot directly on the local MWL; instead, it is shifted to the right along an evaporation trend. An evaporation trend occurs because $\delta^{16} \mathrm{O}$ is fractionated into the vapor phase to a greater extent than $\delta^{2} \mathrm{H}$, and thus the remaining water follows a slope of higher $\delta^{18} \mathrm{O}$ values relative to $\delta^{2} \mathrm{H}$ values. $\delta^{18} \mathrm{O}$ and $\delta^{2} \mathrm{H}$ values of AML 1 water are distinctly different from the other AMLs (i.e., 2 
Fig. 8 Vertical profiles of selected major ions of AML 2
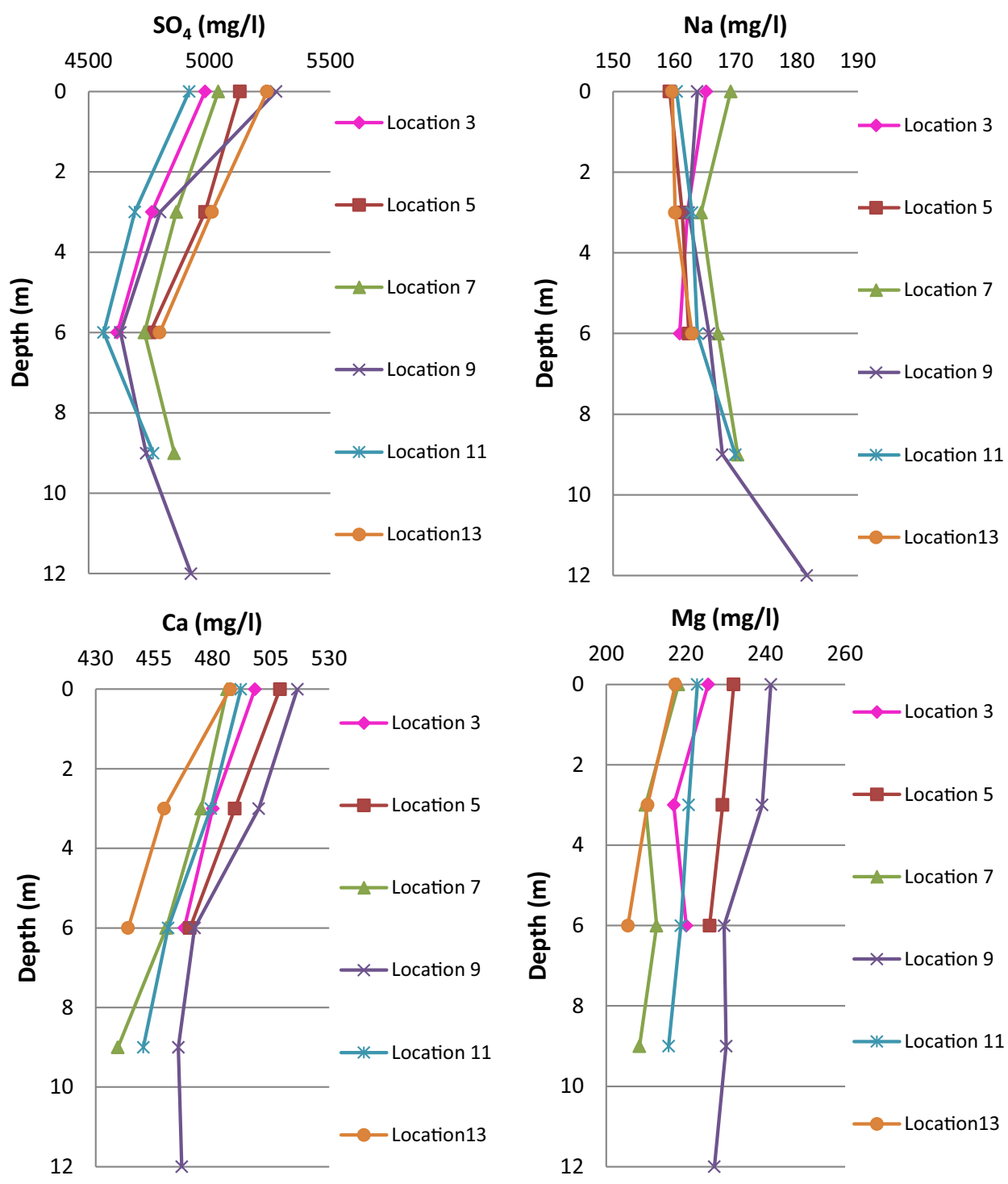

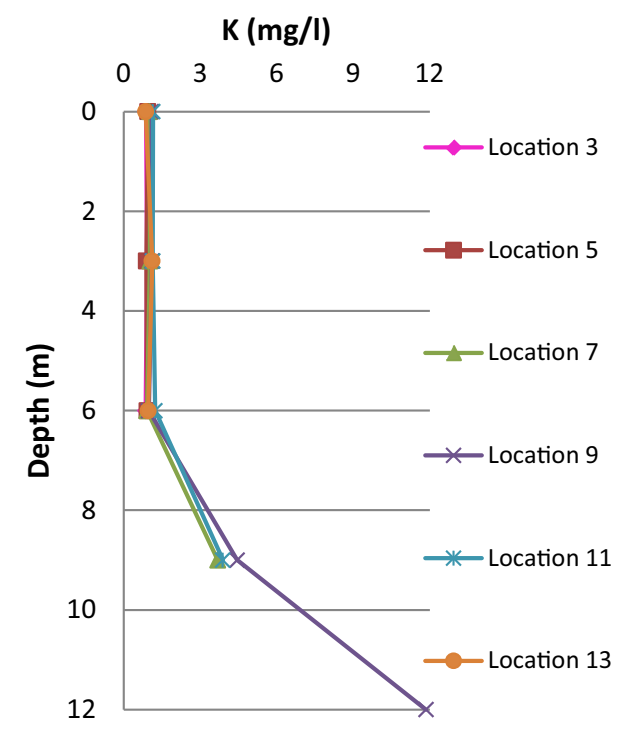


Fig. 9 Some metal characteristics of the water column of AML 2
$\mathrm{Fe}_{\mathrm{t}}(\mathrm{mg} / \mathrm{I})$

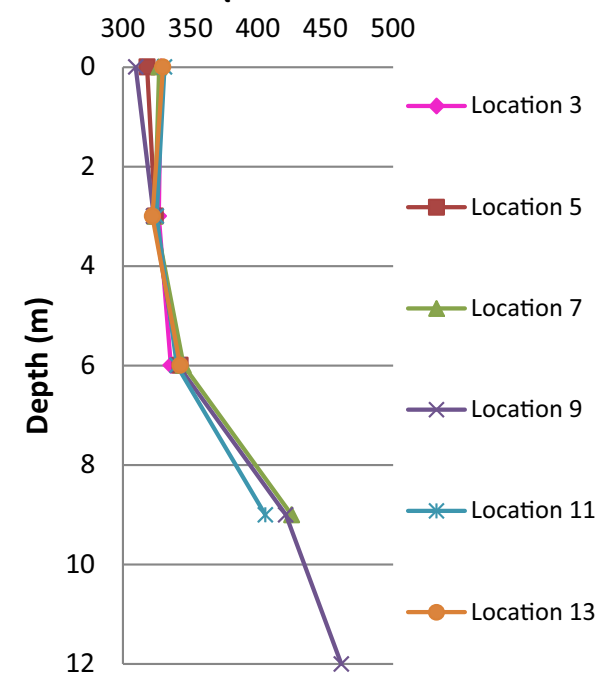

$\mathrm{Mn}$ (mg/l)

170180190200210220

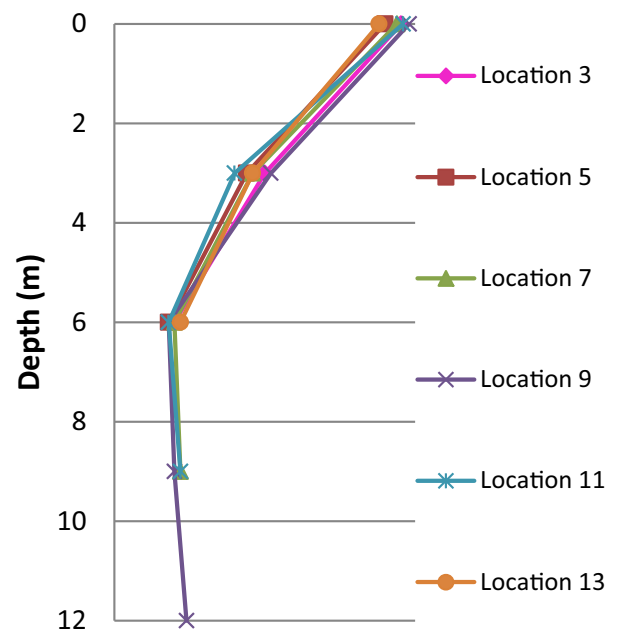

\section{$\mathrm{Ni}(\mathrm{mg} / \mathrm{l})$}

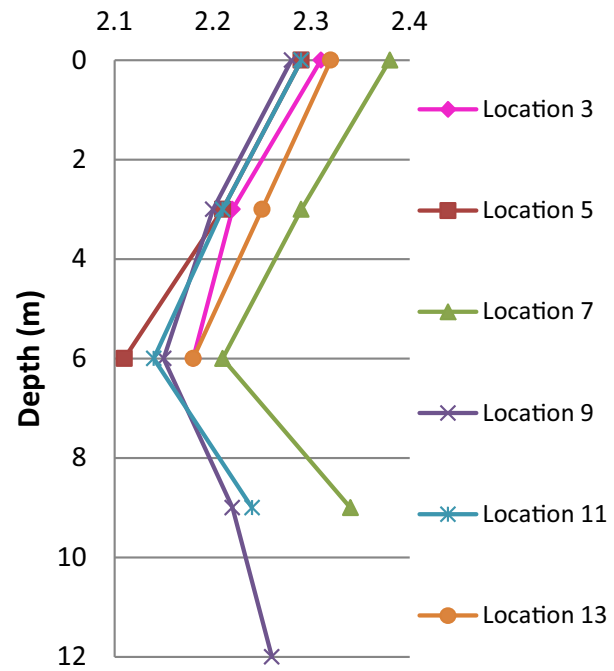

Al (mg/l) 300310320330340350
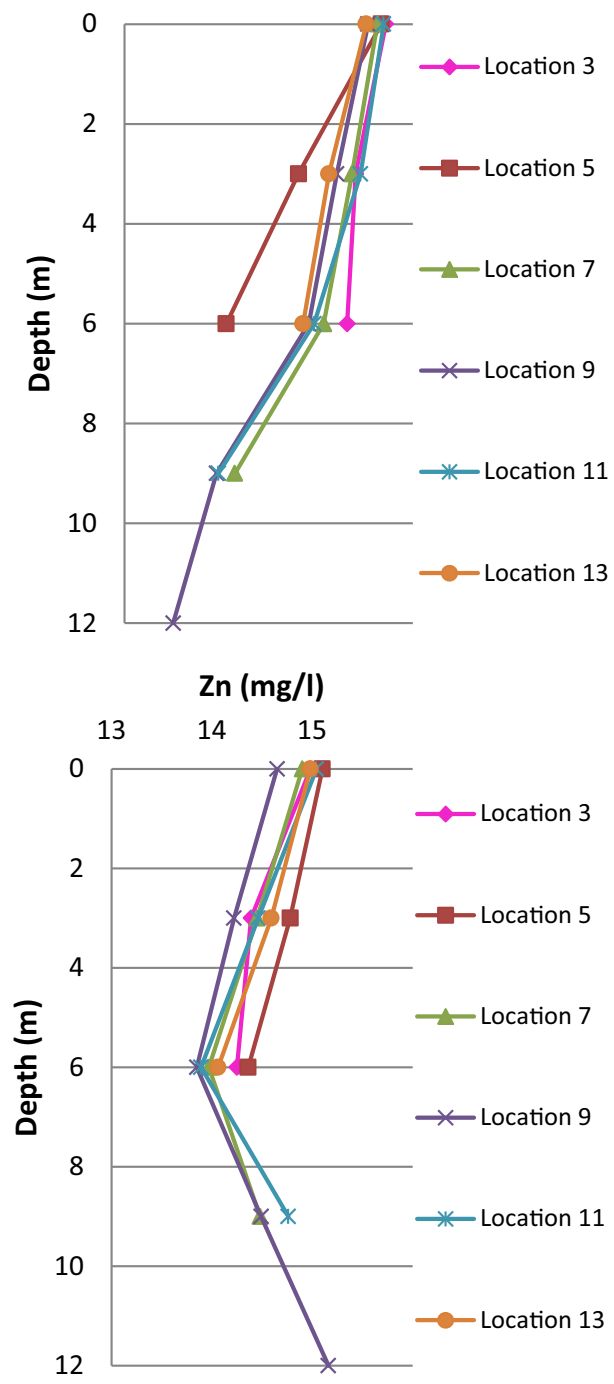
Fig. 10 The isotopic composition of AMLs plotted on $\delta^{18} \mathrm{O}$ versus $\delta^{2} \mathrm{H}$

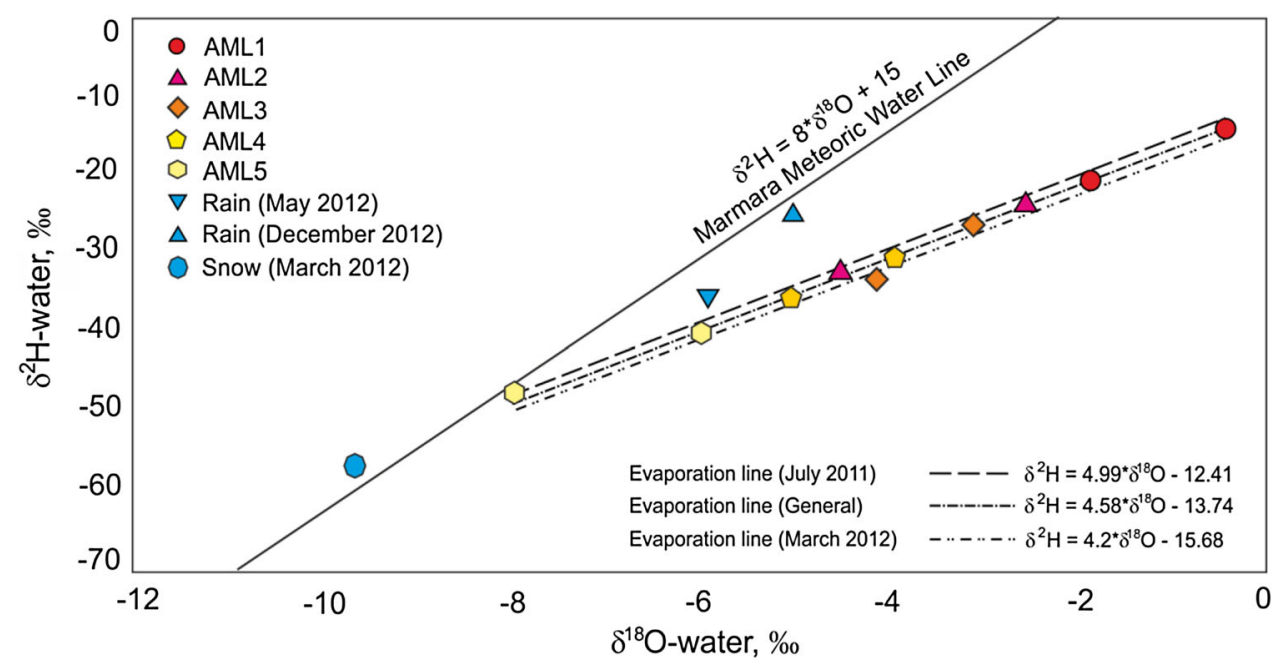

through 5). Among the lakes, the $\delta^{18} \mathrm{O}$ and $\delta^{2} \mathrm{H}$ values of AML 5, the youngest lake, display values more similar to those of rain. The $\delta^{2} \mathrm{H}$ and $\delta^{18} \mathrm{O}$ values of the other lakes (i.e., AMLs 2 through 4) are slightly different than those of rain. Overall, the isotopic composition of all of the lakes reflects varying degree of evaporation, which is correlated with their ages. Consistently, AML 1 has not been drained since 1999 (Sanliyuksel Yucel et al. 2014), and thus evaporation effect and water-rock interaction are more pronounced compared with the other lakes. Overall, the isotope composition of all of the water samples in the study area indicates a technically meteoric origin such as precipitation. This determination is also consistent with the fact that these lakes developed by being fed by the surface waters in the area. One can assume that groundwater may also play an important role in the development of the lakes as suggested in previous studies (Sanliyuksel Yucel and Baba 2013; Sanliyuksel Yucel et al. 2014). In fact, significantly similar $\delta^{18} \mathrm{O}_{\mathrm{H}_{2} \mathrm{O}}$ values between groundwater (-6.72 to $-8.47 \%$ ) and AML 5 (-5.65 and $-7.73 \%$ ) may suggest this possibility. $\delta^{3} \mathrm{H}$ analysis of mine waters can yield information regarding the apparent age or time of travel of water from its area of recharge (Butler 2007). The $\delta^{3} \mathrm{H}$ values in snow during March 2012 were measured as 8.12 and $8.62 \mathrm{TU}$ in the study area. $\delta^{3} \mathrm{H}$ contents of AMLs vary between 5.71 and $10.38 \mathrm{TU}$ and the median value is 7.39 TU indicating modern water, i.e., $<5$ to 10 years old (Clark and Fritz 1997). High $\delta^{3} \mathrm{H}$ contents indicate that lake water has a relatively short passage time and is fed by surface waters, especially creeks. In addition, $\delta^{3} \mathrm{H}$ values may be due to the fact that AMLs interact with the atmosphere and are thus affected by atmospheric phenomenon more than surrounding water resources.

The isotopic composition of dissolved $\mathrm{SO}_{4}\left(\delta^{18} \mathrm{O}_{\mathrm{SO}_{4}}\right.$, $\delta^{34} \mathrm{~S}_{\mathrm{SO}_{4}}$ ) from the lake water samples is presented in Table 4. The $\delta^{34} \mathrm{~S}$ values of dissolved sulfate ranged from -12.2 to $-14.0 \%$ among the lakes except AML 3 . The similar and minor variations in $\delta^{34} \mathrm{~S}$ values of sulfate imply a similar source of sulfate. In contrast, a significant variability was observed for $\delta^{18} \mathrm{O}$ sulfate values $(-1.7$ to $-7.3 \%$ ). Coal-associated pyrite (CAP) samples from the coal waste and the volcanic rock-associated pyrite (VAP) in the immediate vicinity of the lakes had an average $\delta^{34} \mathrm{~S}$ value of $-13.4 \%$ o $(n=6)$ and $0.8 \%(n=8)$, respectively. Elemental sulfur collected from the mine wastes had an average $\delta^{34} \mathrm{~S}$ value of $-15.9 \%$, and gypsum had a $\delta^{34} \mathrm{~S}$ value of $-10.4 \%$ and a $\delta^{18} \mathrm{O}$ value of $-1.8 \%$ (Table 4 ). It is generally accepted that sulfur isotope effects associated with solidphase metal sulfide oxidation are insignificant compared with the oxidation of aqueous sulfide (Sakai 1957; Nakai and Jensen 1964; McCready and Krouse 1982; Taylor et al. 1984b; Fry et al. 1988). Oxidation of sulfide minerals to sulfate at low temperatures is generally a quantitative and unidirectional process that causes negligible sulfur-isotope fractionation. This often results in $\delta^{34} \mathrm{~S}_{\mathrm{SO}_{4}}$ values being indistinguishable from those of the parent sulfide minerals (Gavelin et al. 1960; Nakai and Jensen 1964; Field 1966; Rye et al. 1992; Balci et al. 2007, 2012). Because negligible and minor fractionation of $\mathrm{S}$ isotopes occurs during the oxidative weathering of sulfide minerals (Field 1966; Seal 2003; Balci et al. 2007, 2012), the $\delta^{34} \mathrm{~S}$ signature of dissolved $\mathrm{SO}_{4}$ in the lakes should be similar to that of the sulfur source. Isotopic sulfur enrichment between aqueous sulfate from the lake water and sulfur sources available in the study area was calculated (Table 4). The largest $\mathrm{S}$ isotope enrichment, $-13.75 \%$, was obtained between VAP and sulfate indicating that volcanic pyrite is not likely to be the sulfur source of sulfate. In contrast, insignificant sulfur isotope enrichment $\left(\varepsilon_{\mathrm{SO}_{4}-\mathrm{FeS}_{2} a}=0.44 \%\right.$ o $)$ between $\delta^{34} \mathrm{~S}_{\mathrm{SO}_{4}}$ and $\delta^{34} \mathrm{~S}_{\mathrm{CAP}}$ indicates that the main sulfur source 
Table $4 \mathrm{O}$ and S isotope results and isotopic enrichment of AMLs (\%o)

\begin{tabular}{|c|c|c|c|c|c|c|c|c|}
\hline Sample location & Sampling date & $\delta^{18} \mathrm{O}_{\mathrm{H}_{2} \mathrm{O}}$ & $\delta^{18} \mathrm{O}_{\mathrm{SO}_{4}}$ & $\delta^{34} \mathrm{~S}_{\mathrm{SO}_{4}}$ & $\varepsilon_{S O_{4}-F e S_{2}}{ }^{a}$ & $\varepsilon_{\mathrm{SO}_{4}-\mathrm{FeS}_{2}}{ }^{\mathrm{b}}$ & $\varepsilon_{S_{4}-S}{ }^{c}$ & $\varepsilon_{\mathrm{SO}_{4}-\text { gypsum }}{ }^{\mathrm{d}}$ \\
\hline \multirow[t]{4}{*}{ AML 1} & November 2009 & -2.5 & -6.2 & - & - & - & - & - \\
\hline & November 2010 & -3.2 & 18 & - & - & - & - & - \\
\hline & July 2011 & -0.08 & -6.9 & -12.3 & 1.1 & -13.1 & 3.6 & -1.9 \\
\hline & March 2012 & -1.65 & -7.3 & -12.4 & 1 & -13.2 & 3.5 & -2 \\
\hline \multirow[t]{4}{*}{ AML 2} & November 2009 & -2.5 & -7.2 & - & - & - & - & - \\
\hline & November 2010 & -3.2 & 20.6 & - & - & - & - & - \\
\hline & July 2011 & -2.32 & -6 & -12.3 & 1.1 & -13.1 & 3.6 & -1.9 \\
\hline & March 2012 & -4.14 & -6.2 & -12.2 & 1.2 & -13 & 3.7 & -1.8 \\
\hline \multirow[t]{3}{*}{ AML 3} & July 2011 & -2.82 & -1.7 & -20.3 & -6.9 & -21.1 & -4.4 & -9.9 \\
\hline & November 2011 & -3.4 & -1.9 & - & - & - & - & - \\
\hline & March 2012 & -3.91 & -1.7 & -20.1 & -6.7 & -20.9 & -4.2 & -9.7 \\
\hline \multirow[t]{3}{*}{ AML 4} & July 2011 & -3.64 & -2.7 & - & - & - & - & - \\
\hline & November 2011 & -4.5 & -3.6 & - & - & - & - & - \\
\hline & March 2012 & -4.74 & -3.2 & -14 & -0.6 & -14.8 & 1.9 & -3.6 \\
\hline \multirow[t]{3}{*}{ AML 5} & July 2011 & -5.67 & -1.8 & -13.8 & -0.4 & -14.6 & 2.1 & -3.4 \\
\hline & November 2011 & -5.6 & -4.2 & - & - & - & - & - \\
\hline & March 2012 & -7.73 & -4 & -13.7 & -0.3 & -14.5 & 2.2 & -3.3 \\
\hline
\end{tabular}

${ }^{\mathrm{a}} \delta^{34} \mathrm{~S}$ of coal-associated pyrite, $-13.4 \%(n=4)$

b $\delta^{34} \mathrm{~S}$ of volcanic rock-associated pyrite, $\delta^{34} \mathrm{~S}+0.8 \%$ o $(n=3)$

c $\delta^{34} \mathrm{~S}$ of sulfur from Can coal, $-15.9 \%$

${ }^{\mathrm{d}}$ Gypsum, $\delta^{34} \mathrm{~S}-10.4 \%$, $\delta^{18} \mathrm{O}-1.8 \%$

of sulfate in AMLs is CAP. Moreover, the fact that the $\delta^{34} \mathrm{~S}$ value of $S^{0}$ was similar to the $\delta^{34} S$ value of pyrite in the waste deposit is strong evidence that the original source of $S^{0}$ in the waste deposit is the weathering of pyrite. A significant elemental sulfur formation has been shown in the oxidation of pyrite during the formation of AMD and further oxidation to sulfate (Sasaki et al. 1995; Schippers et al. 1996; McGuire et al. 2001; Druschel et al. 2003; Balci et al. 2007, 2012). A distinct difference between the $\delta^{34} \mathrm{~S}$ value of VAP and those of aqueous sulfate from the lakes indicates that most of the sulfate in the lake must have been derived from the oxidation of pyrite associated with coal in addition to the oxidation of elemental sulfur as well as other sources such as leaching of hypogene sulfate minerals. The $\delta^{34} \mathrm{~S}_{\mathrm{SO}_{4}}$ values from AML 3 are distinctly different compared with those of the other lakes. These values could be a result of mixing with the Katran Creek cutting various mineralization zones and fed by various surface waters containing different sources of sulfate.

\section{Geochemical and Biogeochemical Processes in the Water Column and Sediments of AML 2}

The oxidation of reduced sulfur (e.g., pyrite) and sulfur contained in the coal, mine wastes, and surrounding volcanic rocks, together with the absence of acid-consuming rocks, causes acidity, sulfate, $\mathrm{Fe}(\mathrm{II})$, and metals to develop in the water column. The elevated concentrations of $\mathrm{As}, \mathrm{Co}, \mathrm{Cu}, \mathrm{Ni}, \mathrm{Zn}$, and $\mathrm{Pb}$ in coal and volcanic rocks in the vicinity of the study area are released into the water column during the oxidation of reduced sulfur and further transported into the lake sediments. The correlation between total dissolved sulphur content and the age of the lakes further supports enhanced water-rock interactions in the lakes (Table 3). The most important parameters that control lake water chemistry are $\mathrm{pH}$ and Eh because the mobility of most metals and metalloids is strongly $\mathrm{pH}$ - and Eh-dependent. Throughout the water column of AML $2 \mathrm{pH}$ showed a slightly increasing trend (from 3.04 to 3.85). Variations in $\mathrm{pH}, \mathrm{DO}$, and dissolved Fe with depth showed that the microbial oxidation of $\mathrm{Fe}(\mathrm{II})_{\mathrm{aq}}$ to $\mathrm{Fe}(\mathrm{III})_{\mathrm{aq}}$, as well as the subsequent precipitation of Fe-oxides, is thermodynamically more favored in the first $6 \mathrm{~m}$ of the water column.

Consistent with this, the majority of $\mathrm{Fe}_{\mathrm{t}}$ was in the form of $\mathrm{Fe}(\mathrm{III})_{\mathrm{aq}}$ irrespective of sampling season (97\% in July and $76 \%$ in March) (see Table 3). The presence of bacterial species with closest affiliation to Fe-oxidizer bacteria (Acidithiobacillus spp.) indicates that the microbial oxidation of $\mathrm{Fe}(\mathrm{II})$ is a significant biogeochemical process in 
the sediments of AML 2 as noted in previous studies (e.g., Friedrich et al. 2005; Rohwerder and Sand 2007; Ghosh and Dam 2009; Schippers et al. 2010; Dopson and Johnson 2012; Chen et al. 2013).

Insignificant variations in $\mathrm{pH}$, along with observed changes in $\mathrm{DO}$ and $\mathrm{Fe}$ concentration throughout the water column until a depth of $6 \mathrm{~m}$, also suggest co-occurrences of $\mathrm{Fe}$ (II) oxidation and precipitation of $\mathrm{Fe}(\mathrm{III})$ minerals buffering $\mathrm{pH}$ as reported in various AMLs with $\mathrm{pH}$ ranging from 2.59 to 3.79 (Kusel 2003; Peiffer et al. 2013; Vithana et al. 2015). A decrease in the concentration of sulfate in the first $6 \mathrm{~m}$ of the water column further supports the formation of $\mathrm{Fe}(\mathrm{III})$ minerals (e.g., jarosite). With depth, increasing $\mathrm{pH}$ and lower oxygenic character of the water column creates unfavorable conditions for $\mathrm{Fe}$ oxidizers in the lake (Fig. 7; Table 5). It is known that Fe(II) oxidation by acidophilus (e.g., Acidithiobacillus ferrooxidans) rapidly decreases with increasing pH (Pesic et al. 1989; Nordstrom and Southam 1999; Kupka and Kupsakova 1999).

The Fe(III) minerals (e.g., jarosite and lepidocrocite) formed in the water column further accumulate in the sediments where they may undergo chemical transformations. XRD patterns and SEM images of the lake sediments, together with the decrease in $\mathrm{Fe}$ and sulfate concentration until a depth of $6 \mathrm{~m}$, indicate Fe(III) mineral precipitation in the water column. $\mathrm{pH}$ buffering throughout the water column by way of the precipitation of $\mathrm{Fe}$ (III) has a significant effect on metal mobility. Decreases in the concentrations of $\mathrm{Zn}$ and $\mathrm{Ni}$ along with $\mathrm{Fe}$ throughout $6 \mathrm{~m}$ of the water column suggests the coprecipitation of metals with Fe oxides (Regenspurg et al. 2002; Regenspurg and Peiffer 2005; Balci 2010; Vithana et al. 2015). The concentration of $\mathrm{Fe}$ showed increasing trend and the highest concentration of $\mathrm{Fe}$ in all of the sampling points was measured at the sediment-water interface (see Fig. 9). The sharp increase in the concentration of $\mathrm{Fe}$ can be attributed to (1) the dissolution of Fe(III) oxides (e.g., jarosite); (2) the oxidation of pyrite; and (3) an $\mathrm{Fe}$ reduction in the sediments. Jarosite and schwertmannite, formed as result of sulfide oxidation, are the two common $\mathrm{Fe}$ minerals in AMD. Both minerals can transform into thermodynamically more stable phases (e.g., goethite) increasing acidity and releasing previously held trace metals (Reaction 1) (Burton et al. 2007, 2008; Vithana et al. 2015).

$$
\begin{aligned}
\mathrm{KFe}_{3}\left(\mathrm{SO}_{4}\right)_{2}(\mathrm{OH})_{6}+6 \mathrm{H}_{2} \mathrm{O} \rightarrow & \mathrm{K}^{+}+3 \mathrm{Fe}^{3+}+2 \mathrm{SO}_{4}^{2-} \\
& +6 \mathrm{H}^{+} \\
\mathrm{Fe}_{8} \mathrm{O}_{8}(\mathrm{OH})_{6} \mathrm{SO}_{4}+2 \mathrm{H}_{2} \mathrm{O} \rightarrow & \mathrm{SO}_{4}^{2-}+8 \mathrm{FeOOH}+2 \mathrm{H}^{+}
\end{aligned}
$$

Although the presence of schwertmannite in the lake sediments has not been confirmed due to its low crystallinity, the dissolution and transformation of it cannot be neglected due to the chemical characteristics of the lake (Regenspurg et al. 2004; Schwertmann and Carlson 2005). Dissolution Reactions (1) and (2) may help to maintain low $\mathrm{pH}$ conditions and explain the increasing trend observed in the metal content of the water column. Particularly, a sharp increase in $\mathrm{K}$ and sulfate is further evidence for the dissolution of $\mathrm{Fe}$ (III) sulfate minerals in the lake water as shown in Reactions (1) and (2) (Elwood Madden et al. 2012). Reductive dissolution of $\mathrm{Fe}(\mathrm{III})$ minerals in the sediments by way of microbial processes is also possible at the water-sediment interface (Regenspurg et al. 2002). Many Fe-reducing bacteria (e.g., Ferribacterium limneticum, Geobacter, and uncultured Geobacteraceae bacterium) determined in the sediments (Table 5), along with lower Eh and DO values measured at the water-sediment interface, indicate $\mathrm{Fe}$ reduction. The consumption of $\mathrm{Fe}(\mathrm{III})$ minerals as an electron acceptor by microorganisms is a common biogeochemical process in AMLs (Peine et al. 2000; Blodau 2004, 2006; Balci et al. 2014). Microorganisms preferentially use $\mathrm{Fe}(\mathrm{III})$ minerals with low crystallinity due to low energy requirements (Johnson et al. 2012). The preferential use of schwertmannite over jarosite by microorganisms as an electron acceptor may explain its low abundance or the absence of schwertmannite in the lake sediments. The reduction of $\mathrm{Fe}$ minerals can consume protons but releases $\mathrm{Fe}(\mathrm{II})$, sulfate, and metals, which are later diffused into the water. The reoxidation of $\mathrm{Fe}$ (II) to $\mathrm{Fe}$ (III) and the subsequent formation and precipitation of $\mathrm{Fe}(\mathrm{III})$ minerals cause an enhanced $\mathrm{Fe}$ cycle that regulates metal mobility at the water-sediment interface.

Biological and chemical oxidation of pyrite by way of Reactions (3) and (4), respectively, may also provide $\mathrm{Fe}(\mathrm{II})$, sulfate, and protons into water. Numerous sulfuroxidizing bacteria determined in the lake sediments, particularly A. ferrooxidans, can catalyze Reaction (3) and cause further release of $\mathrm{Fe}(\mathrm{II})$ and sulfate into the water column. The determination of Thiovirga sulfuroxydans and Thiobacillus thiophilus both chemolithoautotrophic, microaerobic sulfur-oxidizing bacteria suggest microbial sulfur oxidation (e.g., elemental sulfur) even in low oxygenic environments. The DO profile of AML 2 suggests that microbial and chemical $\mathrm{Fe}$ (II) oxidation is possible throughout the whole water column. Higher metal content of sediments relative to the water column further indicates metal enrichment by way of $\mathrm{Fe}$ precipitation and/or adsorption to clay minerals in the sediments.

$$
\begin{aligned}
& \mathrm{FeS}_{2}+7 / 2 \mathrm{O}_{2}+\mathrm{H}_{2} \mathrm{O} \rightarrow \mathrm{Fe}^{2+}+2 \mathrm{SO}_{4}^{2-}+2 \mathrm{H}^{+}, \\
& \mathrm{FeS}_{2}+14 \mathrm{Fe}^{3+}+\mathrm{H}_{2} \mathrm{O} \rightarrow 15 \mathrm{Fe}^{2+}+2 \mathrm{SO}_{4}^{2-}+16 \mathrm{H}^{+} .
\end{aligned}
$$

Iron cycling, involving $\mathrm{Fe}(\mathrm{II})$ oxidation mediated primarily by A. ferrooxidans in the oxygenic zones of the lake 
Table 5 Microorganisms determined by 16S rDNA gene sequencing in the lake sediment of AML 2 and their metabolic functions

\begin{tabular}{|c|c|c|c|}
\hline Microorganims & Similarity $(\%)$ & Phylogenetic group & Postulated metabolism \\
\hline A. ferrooxidans strain $\mathrm{S} 1$ & 95 & $\gamma$-Proteobacteria & $\mathrm{Fe}$ and $\mathrm{S}$ oxidation \\
\hline A. ferrooxidans strain SY3 & 96 & $\gamma$-Proteobacteria & $\mathrm{Fe}$ and $\mathrm{S}$ oxidation \\
\hline A. ferrooxidans strain N16 & 93 & $\gamma$-Proteobacteria & $\mathrm{Fe}$ and $\mathrm{S}$ oxidation \\
\hline Acidithiobacillus sp. Peru 6 & 92 & $\gamma$-Proteobacteria & $\mathrm{Fe}$ and $\mathrm{S}$ oxidation \\
\hline Acidithiobacillus sp. OP 14 & 92 & $\gamma$-Proteobacteria & $\mathrm{Fe}$ and $\mathrm{S}$ oxidation \\
\hline A. albertensis strain DSM 14366 & 93 & $\gamma$-Proteobacteria & \\
\hline A. thiooxidans strain ATCC 19377 & 95 & $\gamma$-Proteobacteria & $\mathrm{Fe}$ and $\mathrm{S}$ oxidation \\
\hline Acidithiobacillus sp. lsh-01 & 92 & $\gamma$-Proteobacteria & $\mathrm{Fe}$ and $\mathrm{S}$ oxidation \\
\hline A. ferrooxidans & 94 & $\gamma$-Proteobacteria & $\mathrm{Fe}$ and $\mathrm{S}$ oxidation \\
\hline Uncultured bacterium clone FZ-7 & 95 & $\gamma$-Proteobacteria & \\
\hline Uncultured Acidithiobacillus sp. clone XJ79 & 96 & & $\mathrm{Fe}$ and $\mathrm{S}$ oxidation \\
\hline Acidithiobacillus sp. Mc9KA-2-1-4 & 95 & $\gamma$-Proteobacteria & $\mathrm{Fe}$ and $\mathrm{S}$ oxidation \\
\hline Uncultured Acidithiobacillus sp. clone AS3_bact_h10 & 95 & $\gamma$-Proteobacteria & $\mathrm{Fe}$ and $\mathrm{S}$ oxidation \\
\hline Uncultured bacterium clone $S X 2-15$ & 96 & $\gamma$-Proteobacteria & \\
\hline A. thiooxidans strain ATCC 19377 & 93 & $\gamma$-Proteobacteria & $\mathrm{S}$ oxidation \\
\hline Uncultured bacterium clone $\mathrm{Z} 132$ & 93 & & \\
\hline Uncultured bacterium clone Y1-25 & 91 & & \\
\hline Uncultured bacterium clone M1-24 & 91 & & \\
\hline Uncultured Sulfobacillus sp. clone K6-C156 & 92 & Firmicutes & $\mathrm{Fe}$ and $\mathrm{S}$ oxidation/Fe reduction \\
\hline A. thiooxidans strain ABRM2011 & 91 & $\gamma$-Proteobacteria & S oxidation \\
\hline A. ferrooxidans strain $\mathrm{S} 1$ & 97 & $\gamma$-Proteobacteria & $\mathrm{Fe}$ and $\mathrm{S}$ oxidation \\
\hline T. sulfuroxydans & 97 & $\gamma$-Proteobacteria & $\mathrm{S}$ oxidation \\
\hline T. thiophilus & 94 & $\beta$-Proteobacteria & S oxidation \\
\hline T. denitrificans ATCC 25259 & 97 & $\beta$-Proteobacteria & $\mathrm{Fe}$ and $\mathrm{S}$ oxidation \\
\hline T. denitrificans ATCC 25259 & 97 & $\beta$-Proteobacteria & $\mathrm{Fe}$ and $\mathrm{S}$ oxidation \\
\hline Uncultured Thiobacillus sp. clone ENR10 & 93 & $\beta$-Proteobacteria & $\mathrm{S}$ oxidation \\
\hline A. thiooxidans strain ABRM2011 & 91 & $\gamma$-Proteobacteria & $\mathrm{S}$ oxidation \\
\hline A. ferrooxidans strain $\mathrm{S} 1$ & 97 & $\gamma$-Proteobacteria & $\mathrm{Fe}$ and $\mathrm{S}$ oxidation \\
\hline T. sulfuroxydans & 97 & $\gamma$-Proteobacteria & $\mathrm{S}$ oxidation \\
\hline Geobacter & 91 & $\delta$-Proteobacteria & Fe reduction \\
\hline Uncultured Geobacteraceae bacterium & 91 & $\delta$-Proteobacteria & Fe reduction \\
\hline F. myxofaciens strain $\mathrm{P} 3 \mathrm{G}$ & 95 & $\delta$-Proteobacteria & Fe oxidation \\
\hline Comamonadaceae bacterium PIV81 & 90 & $\beta$-Proteobacteria & \\
\hline Chromatiales bacterium & 94 & $\beta$-Proteobacteria & \\
\hline Acidovorax sp. G8B1 & 97 & $\gamma$-Proteobacteria & Fe oxidation \\
\hline Uncultured Sulfobacillus sp. clone SN1_2009_10D & 91 & Firmicutes & \\
\hline F. limneticum & 94 & $\beta$-Proteobacteria & Fe reduction \\
\hline T. denitrificans ATCC 25259 & 97 & $\beta$-Proteobacteria & $\mathrm{S}$ oxidation \\
\hline
\end{tabular}

and Fe reduction by Ferribacterium limneticum in the microaerophilic zone, maintains the Fe dynamics of the lake. Enhanced Fe cycles buffering $\mathrm{pH}$, as in AML 2, have been reported in various AMLs (Peine et al. 2000; Blodau 2004, 2006). Blodau (2006) reviewed acid generation and consumption in acid coal mine lakes and concluded that acidification is primarily caused by the generation of ferrous $\mathrm{Fe}$ and subsequent $\mathrm{Fe}$ oxidation and precipitation as shown in this study. In contrast to $\mathrm{Fe}$ reduction, sulfate reduction seems to be an insignificant part of microbial processes in the sediments of AML 2 because no sulfatereducing bacteria were determined (Table 5). Consistent with this determination, Koschorreck (2008) investigated the activity level of sulfate-reducing bacteria in an AMD system and concluded that the high energy required to maintain elevated $\mathrm{pH}$ around the sulfate-reducing bacteria 
make these reactions energetically unfavorable in AMD systems, as is the case in our study.

\section{Mechanism of Pyrite Oxidation and Origin of Water and Sulfate in AMLs}

Chemical and isotopic analyses indicate that the potential source of sulfate in the examined AMLs water is primarily pyrite oxidation. This is particularly consistent with the high pyrite content of coal, mine waste, and lake sediments in addition to elevated concentrations of $\mathrm{Fe}$ in the lake water and sediment. Widespread formation of jarosite in the lake sediments and mine wastes further supports the theory of pyrite dissolution in the lakes (Rye and Alpers 1997).

Oxidation of pyrite in AMD systems is generally described by Reactions (3) and (4) (Garrels and Thompson 1960; Singer and Stumm 1970; Taylor et al. 1984a, 1984b; Nordstrom and Alpers 1999; Nordstrom and Southam 1999). It is shown that the rate of Reaction (3) is enhanced by a number of Acidithiobacillus spp. such as A. ferrooxidans and the reaction rate is limited by the availability of DO. Therefore, Reaction (3) may represent the common reaction for pyrite oxidation under $\mathrm{O}_{2}$-saturated conditions. Ferric iron $\left(\mathrm{Fe}(\mathrm{III})_{\mathrm{aq}}\right)$ can rapidly oxidize pyrite abiotically and anaerobically by way of Reaction (4); to maintain Reaction (4), however, Fe(III) $)_{\mathrm{aq}}$ must be generated by Reaction (5).

$\mathrm{Fe}^{2+}+1 / 4 \mathrm{O}_{2}+\mathrm{H}^{+} \rightarrow \mathrm{Fe}^{3+}+1 / 2 \mathrm{H}_{2} \mathrm{O}$

Under acidic conditions $(\mathrm{pH}<3)$, it is suggested that Reaction (5) can be the rate-limiting step for Reaction (4), and bacterial oxidation of $\mathrm{Fe}^{2+}$ at this low $\mathrm{pH}$ is several orders of magnitude faster than abiotic oxidation (Singer and Stumm 1968; Nordstrom and Alpers 1999; Schippers et al. 1996; Schippers and Sand 1999). Therefore, generation of $\mathrm{Fe}(\mathrm{III})_{\mathrm{aq}}$ by way of Reaction (5) is generally mediated by bacteria in AMD sites.

Based on the stoichiometry of Reactions (3) or (4), oxygen to produce sulfate may come from either molecular oxygen $\left(\mathrm{O}_{2}\right)$ or water $\left(\mathrm{H}_{2} \mathrm{O}\right)$ during pyrite oxidation. The large contrast in the oxygen isotope composition of molecular oxygen in the atmosphere $\left(\delta^{18} \mathrm{O}=+23.5 \%\right.$ o and typical meteoric water $\left(\delta^{18} \mathrm{O}<0 \%\right)$ may provide an opportunity to show the oxidation pathways for pyrite by determining the relative source of oxygen in sulfate based on its measured $\delta^{18} \mathrm{O}_{\mathrm{SO}_{4}}$ value (Taylor et al. 1984a). The following mass balance equation can be used to calculate the relative proportions of oxygen derived from water and molecular oxygen:

$$
\begin{aligned}
\delta^{18} \mathrm{O}_{\mathrm{SO}_{4}^{2-}}= & X\left(\delta^{18} \mathrm{O}_{\mathrm{H}_{2} \mathrm{O}}+\varepsilon_{\mathrm{SO}_{4}-\mathrm{H}_{2} \mathrm{O}}\right) \\
& +(1-X)\left(\delta^{18} \mathrm{O}_{\mathrm{O}_{2}}+\varepsilon_{\mathrm{SO}_{4}-\mathrm{O}_{2}}\right)
\end{aligned}
$$

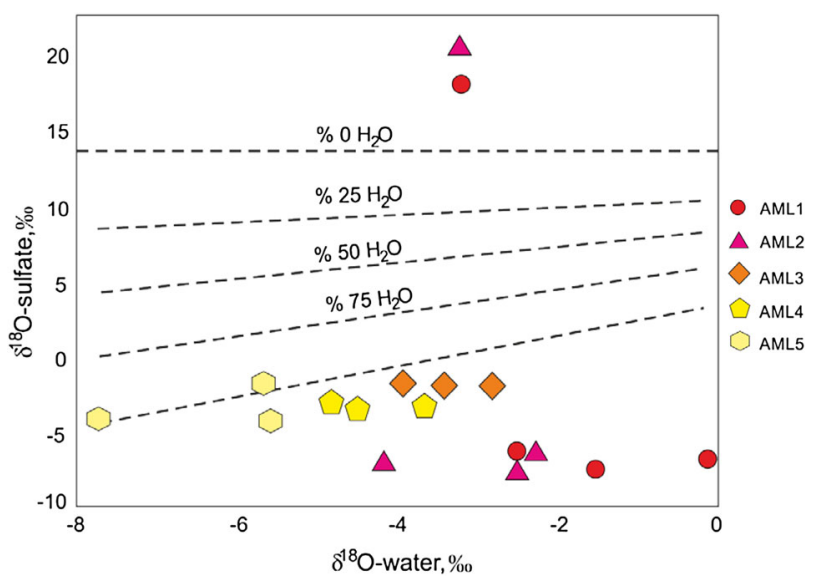

Fig. $11 \delta^{18} \mathrm{O}_{\mathrm{H}_{2} \mathrm{O}}$ versus $\delta^{18} \mathrm{O}_{\mathrm{SO}_{4}}$ values for all lake water samples from the AMLs. The dashed lines represent different percentages of oxygen incorporated from water into sulfate calculated via Eq. (6), assuming enrichment factors $\varepsilon_{\mathrm{SO}_{4}-\mathrm{O}_{2}}-10.8 \%$ and $\varepsilon_{\mathrm{SO}_{4}-\mathrm{H}_{2} \mathrm{O}}+3.1 \%$ and a $\delta^{18} \mathrm{O}$ value for atmospheric oxygen of $+23 \%$

where $\mathrm{X}$ is the fraction of oxygen derived from $\mathrm{H}_{2} \mathrm{O}$; $(1-\mathrm{X})$ is the remaining fraction from $\mathrm{O}_{2}$; and $\varepsilon_{\mathrm{SO}_{4}-\mathrm{H}_{2} \mathrm{O}}$ and $\varepsilon_{\mathrm{SO}_{4}-\mathrm{O}_{2}}$ are the kinetic isotope fractionation effects between $\mathrm{SO}_{4}{ }^{2-}-\mathrm{H}_{2} \mathrm{O}$ and $\mathrm{SO}_{4}{ }^{2-}-\mathrm{O}_{2}$, respectively (Balci et al. 2007, 2012). The enrichment factors $\left(\varepsilon_{\mathrm{SO}_{4}-\mathrm{H}_{2} \mathrm{O}}\right.$ and $\left.\varepsilon_{\mathrm{SO}_{4}-\mathrm{O}_{2}}\right)$ scatter widely under different environmental conditions. The $\varepsilon_{\mathrm{SO}_{4}-\mathrm{O}_{2}}$ values range from 0 to $11.4 \%$ (Taylor et al. 1984a; Van Stempvoort and Krouse 1994; Balci et al. 2007). Taylor et al. (1984a, 1984b) and Balci et al. (2007) determined the $\varepsilon_{\mathrm{SO}_{4}-\mathrm{O}_{2}}$ values as -11.4 and $-10.8 \%$ for biological oxidation of pyrite, respectively. The $\varepsilon_{\mathrm{SO}_{4}-\mathrm{H}_{2} \mathrm{O}}$ values ranged from 0 to $4 \%$ (Holt and Kumar 1991; Balci et al. 2007; Hoefs 2009) under conditions typical for the formation of AMD. These values of enrichment factors are the most suitable for this study.

Figure 11 plots $\delta^{18} \mathrm{O}_{\mathrm{SO}_{4}}$ versus $\delta^{18} \mathrm{O}_{\mathrm{H}_{2} \mathrm{O}}$ for the water samples from the lakes collected in this study. The dashed lines are superimposed data calculated using enrichment factors and the measured $\delta^{18} \mathrm{O}_{\mathrm{H}_{2} \mathrm{O}}$ values based on Eq. (6) and show the percentage of water-derived oxygen during the formation of $\mathrm{SO}_{4}{ }^{2-}$ from pyrite oxidation by way of Reactions (3) and/or (4). Most of the lake water samples, except for AML 5 , plot outside the $0-100 \%$ water-derived oxygen line with the enrichment factors of Taylor et al. (1984a, b) and Balci et al. (2007). If Reaction (4) is the dominant oxidation mechanism for pyrite, then $100 \%$ of the $\mathrm{O}$ atoms in the sulfate must come from water. If $\mathrm{pH}$ is low and $\mathrm{O}_{2}$ is present, then some combination of Reactions (3) and (4) will apply.

Due to the evaporation effect, the lake water has an average $\delta^{18} \mathrm{O}$ value of $-3.4 \%$, which is approximately $4 \%$ heavier than that of groundwater (average $-7.2 \%$ ). By using Eq. (6) and enrichment factors of Taylor et al. (1984a, 
b) and Balci et al. (2007) and assuming that $100 \%$ of oxygen was derived from nonevaporated rain water $(-6.9 \%)$, then in AMLs in situ pyrite oxidation would produce sulfate with an average $\delta^{18} \mathrm{O}$ value of $-3.4 \%$. Particularly the $\delta^{18} \mathrm{O}_{\mathrm{SO}_{4}}$ values from young AMLs 4 (November 2011) and AML 5 (November 2011, March 2012) are in good agreement with the calculated values, indicating in situ pyrite oxidation by way of Reaction (3) and/or (4) and less evaporation effect on the $\delta^{18} \mathrm{O}_{\mathrm{SO}_{4}}$ values. One hundred percent water-oxygen incorporation into sulfate from AML 5 indicates that Reaction (4) is the dominant oxidation mechanism for pyrite in the lake (Fig. 11). Compared with AMLs 4and 5, the $\delta^{18} \mathrm{O}$ enrichment in $\delta^{18} \mathrm{O}_{\mathrm{SO}_{4}}$ values $(-2.7$ to $-1.9 \%$ ) from AML 3 reflects the evaporation effect more, which is also consistent with $\delta^{2} \mathrm{H}$ and $\delta^{3} \mathrm{H}$ values of water (Table 4). In contrast to the other lakes, the $\delta^{18} \mathrm{O}_{\mathrm{SO}_{4}}$ values (-7.3 to $20.6 \%$ ) from the oldest AML 1 to AML 2 are even more scattered and plot outside the superimposed data. Interestingly, even though the $\delta^{18} \mathrm{O}_{\mathrm{H}_{2} \mathrm{O}}$ values from the oldest lakes, AML 1 and AML 2, clearly reflect the evaporation effect, the $\delta^{18} \mathrm{O}_{\mathrm{SO}_{4}}$ values $\left(\delta^{18} \mathrm{O}_{\mathrm{SO}_{4}} \ll \delta^{18} \mathrm{O}_{\mathrm{H}_{2} \mathrm{O}}\right)$ appeared not to or only to slightly reflect evaporation (Table 4; Figs. 10, 11). Similar to this study, Pellicori et al. (2005) also reported the $\delta^{18} \mathrm{O}_{\mathrm{SO}_{4}}$ values with no evaporation influence from highly evaporated water of Yankee Doodle tailings pond $\left(\delta^{18} \mathrm{O}_{\mathrm{SO}_{4}} \ll \delta^{18} \mathrm{O}_{\mathrm{H}_{2} \mathrm{O}}\right)$, Montana, USA. Moreover, extremely heavy $\delta^{18} \mathrm{O}_{\mathrm{SO}_{4}}$ values were obtained from AMLs 1 and 2 (Table 4). These results indicate that sulfate in AMLs 1 and 2 may not be generated by way of in situ pyrite oxidation by Reaction (3) and/or (4) within the lake. If pyrite oxidation occurs in the lake itself, then the product sulfate should enrich in $\delta^{18} \mathrm{O}$ more than those actual measured in the lake water would be expected. Thus, sulfate may be a product of much more complex oxidation/dissolution reactions. Sulfate in AMLs 1 and 2 may come from (1) dissolved sulfate in groundwater, which has no evaporation effect; (2) the dissolution of oxidation products (e.g., gypsum) in the mineralized bedrock or weathered rocks by surface runoff; (3) the release of soluble sulfate salts from the host rocks covering the AML during precipitation events; and (4) the anaerobic oxidation of pyrite by aqueous $\mathrm{Fe}$ (III) from partly or nonevaporated water. The increasing trends of $\mathrm{K}, \mathrm{SO}_{4}$, and $\mathrm{Fe}$ with depth in AML 2 suggest the dissolution of $\mathrm{Fe}$-bearing minerals (e.g., jarosite) common in the lake sediments and mine wastes (see Table 1). Increasing concentrations of $\mathrm{Ni}, \mathrm{Zn}$, and $\mathrm{Mn}$, along with the Fe profile, further support the dissolution of $\mathrm{Fe}$ bearing minerals and the release of sulfate into the water. Most secondary minerals typically form under oxygenic conditions, and the significant incorporation of molecular oxygen would be expected, thus leading to the higher $\delta^{18} \mathrm{O}_{\mathrm{SO}_{4}}$ values. The highest $\delta^{18} \mathrm{O}_{\mathrm{SO}_{4}}$ values of 20.6 and $18 \%$ from AMLs 1 and 2, respectively, may come from such dissolution reactions. The insignificant sulfur isotope fractionation $\left(\varepsilon_{S O_{4}-\text { gypsum }}\right)$ between $\delta^{34} \mathrm{~S}$ gypsum $(-1.8 \%$ ) and the $\delta^{34} \mathrm{~S}_{\mathrm{SO}_{4}}$ values of AMLs 1 and 2 may indicate that dissolution reactions are an additional source of sulfate. Sulfate in lakes AMLs 1 and 2 may also originate from oxidation of pyrite by $\mathrm{Fe}(\mathrm{III})_{\mathrm{aq}}$ (Reaction 3 ) in groundwater or in water that has been partially evaporated. This seems possible because the $\mathrm{pH}$ values of both lakes are in the range where chemical and biological oxidation of $\mathrm{Fe}(\mathrm{II})$ to $\mathrm{Fe}$ (III) is possible (Table 3). In addition, bacterial species determined in AML 2 can catalyze the oxidation of $\mathrm{Fe}$ (II) to $\mathrm{Fe}(\mathrm{III})$ providing a ubiquitous electron donor for pyrite oxidation. Based on the similarity between the $\delta^{18} \mathrm{O}_{\mathrm{SO}_{4}}$ and the $\delta^{18} \mathrm{O}_{\mathrm{H}_{2} \mathrm{O}}$ values of groundwater ranging from -6.72 to $-8.47 \%$ (Sanliyuksel Yucel 2013), it is concluded that pyrite oxidation by $\mathrm{Fe}(\mathrm{III})$ by way of Reaction (4) in groundwater would be the main sulfate source for particularly AML 1. It is shown that each of these sulfate-producing reactions would contribute to some extent to the $\delta^{18} \mathrm{O}_{\mathrm{SO}_{4}}$ values of the lakes, thus making the interpretation of $\delta^{18} \mathrm{O}_{\mathrm{H}_{2} \mathrm{O}}$ versus $\delta^{18} \mathrm{O}_{\mathrm{SO}_{4}}$ values complicated.

The $\delta^{34} \mathrm{~S}$ values of sulfate from all of the lakes ranged from -20.3 to $-12.2 \%$ with a mean value of $-14.5 \%$ (Table 4). Based on the isotopic enrichment factors $\left(\varepsilon_{S O_{4}-F_{e S}}\right)$, it is reasonable to assume that the majority of the sulfate in the lake waters was derived from the oxidation of pyrite in the coal. The $\delta^{34} \mathrm{~S}$ values of -20.3 and $-20.1 \%$ from AMLs 2 and 3, respectively, fall outside the range of the $\delta^{34} \mathrm{~S}_{\mathrm{SO}_{4}}$ obtained from the lakes. The $\delta^{34} \mathrm{~S}$ composition of pyrite in coal can vary over a huge range even in a single coal field due to a number of biological and chemical syngenetic and epigenetic processes during $\mathrm{S}$ incorporation into coal. Smith and Batts (1974) reported that $\delta^{34} \mathrm{~S}$ value of pyrite ranged from -10.3 to $+24.2 \%$. Similarly, Hackley and Anderson (1986) showed a huge variation in the $\delta^{34} \mathrm{~S}$ value of pyrite $(-52.6$ to $+34.6 \%)$ in coal from the Rocky Mountain region. Sulfur isotope fractionation of $2 \%$ for $\mathrm{S}^{0}$ oxidation with A. ferrooxidans has been reported by Balci et al. (2012), which encompasses the value determined in this study, thus indicating that biological oxidation of sulfur, particularly in AML 2, cannot be neglected because numerous sulfur-oxidizing bacteria were determined in the lake as suggested by various studies (McGuire et al. 2001; Druschel et al. 2003, 2004; Baker et al. 2004).

\section{Conclusion}

The AMLs in Can county are highly acidic (pH of 2.59) because of intensive sulfide oxidation and ineffective neutralization processes. The abundance of pyrite in the 
volcanic rocks, coal, mine wastes, and sediments of AML 2, as evidenced by XRD, SEM/EDX, and isotope analyses of sulfate, indicates this mineral is the main sulfide mineral undergoing oxidation in the study area. The hydrochemical and geochemical characteristics are associated with the age of the lakes, which determines the degree of water-rock interactions. Relatively young lakes (AMLs 4 and 5) represent the early stage of AMD generation with low dissolved metal concentrations and low acidity compared with the oldest lakes, AMLs 1 and 2. Major acid-production reaction in the oldest lakes (AMLs 1 and 2) is regulated by the production of ferrous iron, subsequent $\mathrm{Fe}$ oxidation, and precipitation. However, acidification in the young lakes is caused by pyrite oxidation, and $\mathrm{Fe}$ cycles seem to be insignificant in these lakes due to the low Fe content of water and thus low Fe saturation in the water. In AML 2, ferrous iron released by way of pyrite oxidation is oxidized to ferric iron, which then precipitates as jarosite and further increases acidity causing $\mathrm{pH}$ buffering in the water column. The precipitation and dissolution of $\mathrm{Fe}$ minerals has a significant affect on metal cycles in the water column as well as in the lake sediments of AML 2. High abundance of jarosite in the lake sediments, along with high content of metals, further suggests the importance of $\mathrm{Fe}$ cycles on metals. Determination of Fe reducer and oxidizing bacteria in addition to sulfur oxidizing microorganisms indicates active $\mathrm{S}$ and $\mathrm{Fe}$ cycles at the water-sediment interface of AML 2. Increasing Fe concentration with depth, along with low Eh values, suggests the existence of Fe reduction in the sediments. The isotopic composition of lake waters showed an evaporation trend that deviates from the meteoric water line (precipitation line). Water in the oldest lakes shows the largest extent of evaporation, whereas young lakes have relatively low evaporation. $\delta^{18} \mathrm{O}_{\mathrm{SO}_{4}}$ in the oldest lakes is isotopically different from the $\delta^{18} \mathrm{O}_{\mathrm{SO}_{4}}$ values in young lakes, but very similar to the $\delta^{18} \mathrm{O}$ of groundwater and meteoric water, suggesting that in situ pyrite oxidation in the oldest lakes may not be the major source of sulfate. In contrast, $\delta^{18} \mathrm{O}_{\mathrm{SO}_{4}}$ and $\delta^{34} \mathrm{~S}_{\mathrm{SO}_{4}}$ values from the oldest lakes suggest the oxidation of pyrite by $\mathrm{Fe}^{3+}$ in nonevaporative water (e.g., groundwater) and/or dissolution of soluble sulfate salts during wet seasons either through runoff or/ and lake-level rises. Overall, the current study highlighted the difficulties of using $\mathrm{O}$ isotopes of sulfate to elucidate the source of sulfate and the oxidation mechanism of pyrite in AMLs that have undergone varying degree evaporation and intense water-rock interactions.

Acknowledgments The authors are grateful to Mehmet Ali Yucel for support during field work. This study was funded by the Teck Mining Company. Funding was also provided by a TUBITAK grant to N. Balci (108Y177) for isotope analysis. The authors are also thankful for constructive comments by the reviewers.

\section{Compliance with Ethical Standards}

Conflict of Interest The authors declare that they have no conflict of interest.

\section{References}

American Public Health Association (1998) Acidity (2310) titration method. In: Standard methods for the examination of water and wastewater (20th edn). APHA, Washington

Baba A, Gunduz O (2010) Effect of alteration zones on water quality: a case study from Biga Peninsula, Turkey. Arch Environ Contam Toxicol 58:499-513

Baba A, Save D, Gunduz O, Gurdal G, Bozcu M, Sulun S (2009) The assessment of the mining activities in Can Coal Basin from a medical geology perspective. Report of the Scientific and Technological Research Council of Turkey, Ankara

Bachmann TM, Friese K, Zachmann DW (2001) Redox and pH conditions in the water column and in the sediments of an acidic mining lake. J Geochem Explor 73:75-86

Baker BJ, Lutz MA, Dawson SC, Bond PL, Banfield JF (2004) Metabolically active eukaryotic communities in extremely acidic mine drainage. Appl Environ Microbiol 70:6264-6271

Balci N (2010) Effect of bacterial activity on trace metals release from oxidation of sphalerite at low $\mathrm{pH}(<3)$ and implications for AMD environment. Environ Earth Sci 60:485-493

Balci N, Wayne CS, Mayer B, Mandernack K (2007) Oxygen and sulfur isotope systematics of sulfate by bacterial and abiotic oxidation of pyrite. Geochim Cosmochim Acta 71:3796-3811

Balci N, Mayer B, Wayne CS, Mandernack K (2012) Oxygen and sulfur isotope systematics of sulfate produced during abiotic and bacterial oxidation of sphalerite and elemental sulfur. Geochim Cosmochim Acta 77:335-351

Balci N, Gul S, Kilic MM, Karagüler NG, Sari E, Sonmez MS (2014) Biogeochemistry of Balıkesir Balya $\mathrm{Pb}-\mathrm{Zn}$ mine tailings site and its effect on generation of acid mine drainage. Geol Bull Turkey 57:1-24

Balci N, Menekse M, Karaguler NG, Sonmez MS, Meister P (2015) Reproducing authigenic carbonate precipitation in the hypersaline Lake Acıgöl (Turkey) with microbial cultures. Geomicrobiol J. doi:10.1080/01490451.2015.1099763

Banerjee SC (2000) Prevention and combating mine fires. Balkema Publishers, Rotterdam

Bingham JM, Schwertmann U, Traina SJ, Winland RL, Wolf M (1996) Schwertmannite and the chemical modeling of iron in acid sulfate waters. Geochim Cosmochim Acta 60:2111-2121

Blodau C (2004) Evidence for a hydrologically controlled iron cycle in acidic and iron rich sediments. Aquat Sci 66:47-59

Blodau C (2006) A review of acidity generation and consumption in acidic coal mine lakes and their watersheds. Sci Total Environ 369:307-332

Blowes DW, Ptacek CJ, Jambor JL, Weisener CG (2003) The geochemistry of acid mine drainage. Treatise Geochem 9:149-204

Bozcu M, Akgun F, Gurdal G, Yesilyurt SK, Karaca O (2008) Sedimentologic, petrologic, geochemical and palinologic examination of Çan Yenice Bayramic (Çanakkale) lignite basin. Report of the Scientific and Technological Research Council of Turkey, Ankara

Burton ED, Bush RT, Sullivan LA, Mitchell DRG (2007) Reductive transformation of iron and sulfur in schwertmannite-rich accumulations associated with acidified coastal lowlands. Geochim Cosmochim Acta 71:4456-4473 
Burton ED, Bush RT, Sullivan LA, Mitchell DRG (2008) Schwertmannite transformation to goethite via the Fe(II) pathway: reaction rates and implications for iron sulfide formation. Geochim Cosmochim Acta 72:4551-4564

Butler TW (2007) Isotope geochemistry of drainage from an acid mine impaired watershed, Oakland, California. Appl Geochem 22:1416-1426

Chen L, Li J, Chen Y, Huang L, Hua Z, Hu M, Shu W (2013) Shifts in microbial community composition and function in the acidification of a lead/zinc mine tailings. Environ Microbiol 15:2431-2444

Clark ID, Fritz P (1997) Environmental isotopes in hydrogeology. CRC Press, Boca Raton

Cornell RM, Schwertmann U (2003) The iron oxides: structure, properties, reactions, occurrence and uses. Wiley, Weinheim

Cravotta CA (2008a) Dissolved metals and associated constituents in abandoned coal-mine discharges, Pennsylvania, USA. part 1: constituent quantities and correlations. Appl Geochem 23:166-202

Cravotta CA (2008b) Dissolved metals and associated constituents in abandoned coal-mine discharges, Pennsylvania, USA. part 2: geochemical controls on constituent concentrations. Appl Geochem 23:203-226

Dayal A (1984) Petrography of Yenice granite (Çanakkale) and related mines. Doctoral dissertation, geology engineering, graduate school of natural and applied sciences, Dokuz Eylul University

Descostes M, Mercier F, Beaucaire C, Zuddas P, Trocellier P (2001) Nature and distribution of chemical species on oxide pyrite surface: complementarity of XPS and nuclear microprobe analysis. Nucl Instrum Methods Phys Res 181:603-609

Dold B (2010) Basic concepts in environmental geochemistry of sulfidic mine-waste management waste management. In: Kumar ES (ed) Waste management. InTech, Rijeka, pp 173-198

Dold B, Spangerberg JE (2005) Sulfur speciation and stable isotope trends of water-soluble sulfates in mine tailings profiles. Environ Sci Technol 39:5650-5656

Dopson M, Johnson DB (2012) Biodiversity, metabolism and applications of acidophilic sulfur-metabolizing microorganism. Environ Microbiol 14:2620-2631

Druschel GK, Hamers RJ, Banfield JF (2003) Kinetics and mechanism of polythionate oxidation to sulfate at low $\mathrm{pH}$ by $\mathrm{O}_{2}$ and $\mathrm{Fe}^{3+}$. Geochim Cosmochim Acta 67:4457-4469

Druschel GK, Baker BJ, Gihring TM, Banfield JF (2004) Acid mine drainage biogeochemistry at Iron Mountain, California. Geochem Trans 5:13-32

Eary LE (1998) Predicting the effects of evapoconcentration on water quality in mine pit lakes. J Geochem Explor 64:223-236

Eary LE (1999) Geochemical and equilibrium trends in mine pit lakes. Appl Geochem 14:963-987

Ece OI, Schroeder PA, Smilley MJ, Wampler JM (2008) Acidsulphate hydrothermal alteration of andesitic tuffs and genesis of halloysite and alunite deposits in the Biga Peninsula, Turkey. Clay Miner 43:281-315

Elwood Madden ME, Madden AS, Rimstidt JD, Zahrai S, Kendall MR, Miller MA (2012) Jarosite dissolution rates and nanoscale mineralogy. Geochim Cosmochim Acta 91:306-321

Ercan T, Satır M, Sevin D, Turkecan A (1995) Interpretation of new chemical, isotopic and radiometric data on Cenozoic volcanic rocks of Western Anatolia. Direct Miner Res Explor Bull 119:103-112

Ercan HE, Ece OI, Karacık Z (2013) Mineralogical and geochemical characterization of çan volcanics and related kaolin deposits, Canakkale, Turkey. 13th international scientific geoconference, Bulgaria, pp 121-128

Espana JS, Pamo EL, Pastor ES, Ercilla MD (2008) The acidic mine pit lakes of the Iberian Pyrite Belt: an approach to their physical limnology and hydrogeochemistry. Appl Geochem 23:1260-1287

Evangelou VP, Zhang YL (1995) A review: pyrite oxidation mechanisms and acid mine drainage prevention. Crit Rev Environ Sci Technol 25:141-199

Fennemore GG, Neller WC, Davis A (1998) Modelling pyrite oxidation in arid environments. Environ Sci Technol 32:2680-2687

Field CW (1966) Sulfur isotope method for discriminating between sulfates of hypogene and supergene origin. Econ Geol 61:1428-1435

Friedrich CG, Bardischewsky F, Rother D, Quentmeier A, Fischer J (2005) Prokaryotic sulfur oxidation. Curr Opin Microbiol 8:253-259

Friese K, Hupfer M, Schultze M (1998) Chemical characteristics of water and sediment in acidic mining lakes of the Lusatian Lignite District. In: Geller W, Klapper H, Salomons W (eds) Acidic mining lakes. Springer, Berlin, pp 25-45

Fry B, Ruf W, Gest H, Hayes JM (1988) Sulfur isotope effects associated with the non-biological oxidation of sulfide in aqueous solution. Chem Geol 73:205-210

Garrels RM, Thompson ME (1960) Oxidation of pyrite by iron sulfate solution. Am J Sci 258:57-67

Gavelin S, Parwel A, Ryhage R (1960) Sulfur isotope fractionation in sulfide mineralization. Econ Geol 55:510-530

Ghosh W, Dam B (2009) Biochemistry and molecular biology of lithotrophic sulfur oxidation by taxonomically and ecologically diverse bacteria and archaea. FEMS Microbiol 33:999-1043

Growitz DJ, Reed LA, Beard MM (1985) Reconnaissance of mine drainage in the coal fields of eastern Pennsylvanian. United States Geological Survey

Gunduz O, Baba A (2008) Fate of acidic mining lakes in Can lignite district, Turkey. Proceedings of 36th IAH congress, Toyama, pp $1-7$

Gurdal G (2011) Abundances and modes of occurrence of trace elements in the Can coals (Miocene), Canakkale-Turkey. Int J Coal Geol 87:157-173

Gurdal G, Bozcu M (2011) Petrographic characteristics and depositional environment of Miocene Çan coals, Çanakkale-Turkey. Int J Coal Geol 85:143-160

Hackley KC, Anderson TF (1986) Sulfur isotopic variations in lowsulfur coals from the Rocky Mountain region. Geochim Cosmochim Acta 50:1703-1713

Hedin RS, Watzlaf GR, Nairn RW (1994) Passive treatment of acid mine drainage with limestone. J Environ Qual 23:1338-1345

Herlihy AT, Kaufmann PR, Mitch ME (1990) Regional estimates of acid mine drainage impact on streams in the Mid-Atlantic and southeastern United States. Water Soil Air Pollut 50:91-107

Hoefs J (2009) Stable isotope geochemistry. Springer, New York

Holt BD, Kumar R (1991) Oxygen isotope fractionation for understanding the sulphur cycle. In: Krouse HR, Grinenko VA (eds) Stable isotopes in the assessment of natural and anthropogenic sulphur in the environment. Wiley, New York, pp 27-41

Hubbard CG, Black S, Coleman ML (2009) Aqueous geochemistry and oxygen isotope compositions of acid mine drainage from the Río Tinto, SW Spain, highlight inconsistencies in current models. Chem Geol 265:321-334

ITASHY (2005) Regulation on the waters quality on human consumption. Official Gazette dated 17/02/2005, Number: 25730, AnkaraTurkey

Johnson DB, Kanao T, Hedrich S (2012) Redox transformations of iron at extremely low ph: fundamental and applied aspects. Front Microbiol 3:1-13

Jönsson J, Jönsson J, Lövgren L (2006) Precipitation of secondary $\mathrm{Fe}(\mathrm{III})$ minerals from acid mine drainage. Appl Geochem 21:437-445 
Jönsson J, Persson P, Sjöberg S, Lövgren L (2005) Schwertmannite precipitated from acid mine drainage: phase formation, sulphate release and surface properties. Appl Geochem 20:179-191

Karakas G, Brookland I, Boehrer B (2003) Physical characteristics of acidic mining lake 111. Aquat Sci 65:297-307

Kempton JH, Locke W, Atkins D, Nicholson A (2000) Probabilistic quantification of uncertainty in predicting mine pit-lake water quality. Mining Eng 52:59-63

Ketris MP, Yudovich YE (2009) Estimations of clarkes for carbonaceous biolithes: world average for trace element contents in black shales and coals. Int J Coal Geol 78:135-148

Kilham K, Firestone MK, McColl JG (1983) Acid rain and soil microbial activity: effects and their mechanisms. J Environ Qual 12:133-137

Klapper H, Schultze M (1995) Geogenically acidified mining lakesliving conditions and possibilities of restoration. Hydrobiology 80:639-653

Knoller K, Fauville A, Mayer B, Strauch G, Friese K, Veizer J (2004) Sulfur cycling in an acid mining lake and its vicinity in Lusatia, Germany. Chem Geol 204:303-323

Koschorreck M (2008) Microbial sulphate reduction at a low $\mathrm{pH}$. FEMS Microbiol Ecol 64:329-342

Krushensky RD (1976) Neogene calc-alkaline extrusive and intrusive rocks of the Karalar Yesiller area, Northwest Anatolia, Turkey. Bull Volcanol 40:336-360

Kupka D, Kupsakova I (1999) Iron (II) oxidation kinetics in Thiobacillus ferrooxidans in the presence of heavy metals. Proc Metal 9:387-396

Kusel K (2003) Microbial cycling of iron and sulfur in acidic coal mining lake sediments. Water Air Soil Pollut 3:67-90

Kwong YTJ, Lawrence JR (1998) Acid generation and metal immobilization in the vicinity of a naturally acidic lake in Central Yukon Territory, Canada. In: Geller W, Klapper H, Salomons W (eds) Acidic mining lakes: Acid mine drainage, limnology and reclamation. Springer, Berlin, pp 65-86

Li L, Kato C, Horikoshi K (1999) Microbial diversity in sediments collected from the deepest cold-seep area, the Japan Trench. Mar Biotechnol 1:391-400

Mandernack KW, Lynch L, Krouse HR, Morgan MD (2000) Sulfur cycling in wetland peat of the New Jersey Pinelands and its affect on stream water chemistry. Geochim Cosmochim Acta 64:3949-3964

McCready RGL, Krouse HR (1982) Sulfur isotope fractionation during the oxidation of elemental sulfur by Thiobacilli in a Solonetzic soil. Can J Soil Sci 62:105-110

McGuire MM, Jallad KN, Ben-Amotz D, Hamers RJ (2001) Chemical mapping of elemental sulfur on pyrite and arsenopyrite surfaces using near-infrared Raman imaging microscopy. Appl Surf Sci 178:105-115

Menekse M (2012) Investigation of microbial diversity of lake Acigol, a hypersaline lake in southern Turkey, and their influence on biomineralization in the lake. Masters thesis, Department of Advanced Technologies Molecular Biology Genetics and Biotechnology Programme, Graduate School of Science Engineering and Technology, Istanbul Technical University

Migaszewski ZM, Galuszka A, Halas S, Dołęgowska S, Dąbek J, Starnawska E (2008) Geochemistry and stable sulfur and oxygen isotope ratios of the Podwiśniówska pit pond water generated by acid mine drainage (Holy Cross Mountains, south-central Poland). Appl Geochem 23:3620-3634

Miller GC, Lyons WB, Davis A (1996) Understanding the water quality of pit lakes. Environ Sci Technol 30:118-123

Mills AL, Herlihy AT (1985) Microbial ecology and acidic pollution of impoundments. In: Gunnison D (ed) Microbial process in reservoirs. Dr. W Junk Publishers, The Hague, pp 169-189
Nakai N, Jensen ML (1964) The kinetic isotope effect in the bacterial reduction and oxidation of sulfur. Geochim Cosmochim Acta 28:1893-1912

Nordstrom DK (1982) Aqueous pyrite oxidation and the consequent formation of secondary iron minerals. In: Kittrick JA, Fanning DS, Hossner LR (eds) Acid sulfate weathering. Soil Sci Am Pub, pp. $37-56$

Nordstrom DK (2003) Effects of microbiological and geochemical interactions in mine drainage. In: Jambor JL, Blowes DW, Ritchie AIM (eds) Environmental aspects of mine wastes. Mineral Association of Canada Short Course Series, pp 227-238

Nordstrom DK, Alpers CN (1999) Geochemistry of acid mine waters. In: Logsdon GS, Plumlee MB (eds) The environmental geochemistry of mineral deposits Part A Processes methods and health issues., Part A. Processes methods and health issuesSociety of Economic Geologists, Littleton, pp 133-160

Nordstrom DK, Southam G (1999) Geomicrobiology of sulfide mineral oxidation. In: Banfield JF, Nealson KH (eds) Geomicrobiology. Interactions between microbes and minerals. Mineralogical Society of America, pp 361-390

Nordstrom DK, Alpers CN, Ptacek C, Blowes DW (2000) Negative $\mathrm{pH}$ and extremely acidic mine waters from Iron Mountain, California. Environ Sci Technol 34:254-258

Okumusoglu D, Gunduz O (2013) Hydrochemical status of an acidic mining lake in Can-Canakkale, Turkey. Water Environ Res 85:604-620

Ozdilek HG (2013) Rainwater quality in Canakkale between 2010 and 2013. International Conference on Environmental Science and Technology, Nevsehir, p 119

Peiffer S, Knorr KH, Blodau C (2013) The role of iron minerals in the biogeochemistry of acidic pit lakes. In: Geller W, Schultz M, Kleinmann B, Wolkersdorfer C (eds) Acidic pit lakes. The legacy of coal and metal surface mines series. Springer, Berlin, pp 42-57

Peine A, Tritschler A, Küsel K, Peiffer S (2000) Electron flow in an iron-rich acidic sediment-evidence for an acidity-driven iron cycle. Limnol Oceanogr 45:1077-1087

Pellicori DA, Gammons CH, Poulson SR (2005) Geochemistry and stable isotope composition of the Berkeley pit lake and surrounding mine waters, Butte, Montana. Appl Geochem 20:2116-2137

Pesic B, Oliver DJ, Wichlacz P (1989) An electrochemical method of measuring the oxidation rate of ferrous to ferric iron with oxygen in the presence of Thiobacillus ferrooxidans. Biotech Bioeng 33:428-439

Pietsch W (1979) Zur hydrochemischen situation der tagebauseen des lausitzer braunkohlen-reviers. Arch Naturchutz Landschaftsforschung 19:97-115

Regenspurg S, Peiffer S (2005) Arsenate and chromate incorporation in schwertmannite. Appl Geochem 20:1226-1239

Regenspurg S, Gößner A, Peiffer S, Küsel K (2002) Potential remobilization of toxic anions during reduction of arsenated and chromated schwertmannite by the dissimilatory Fe(III)-reducing bacterium Acidiphiliumcryptum JF-5. Water Air Soil Pollut 2:57-67

Regenspurg S, Brand A, Peiffer S (2004) Formation and stability of schwertmannite in acidic mining lakes. Geochim Cosmochim Acta 68:1185-1197

Rigol A, Mateu J, Gonzalez-Nunez R, Rauret G, Vidal M (2009) pH stat vs. single extraction tests to evaluate heavy metals and arsenic leachability in environmental samples. Anal Chim Acta 632:69-79

Rohwerder T, Sand W (2007) Oxidation of inorganic sulfur compounds in acidophilic prokaryotes. Eng Life Sci 7:301-309

Rye RO, Alpers CN (1997) The stable isotope geochemistry of jarosite. United States Geological Survey 
Rye RO, Bethke PM, Wasserman MD (1992) The stable isotope geochemistry of acid sulfate alteration. Econ Geol 87:225-262

Sakai H (1957) Fractionation of sulfur isotopes in nature. Geochim Cosmochim Ac 12:150-169

Sanliyuksel Yucel D (2013) Characteristics of acidic water resources, factors enabling their formation and hydrogeochemical properties (Can-Bayramic; Biga Peninsula). Doctoral dissertation in Geology Engineering, Graduate School of Natural and Applied Sciences, Canakkale Onsekiz Mart University

Sanliyuksel Yucel D, Baba A (2013) Geochemical characterization of acid mine lakes and their effect on the environment, NW of Turkey. Arch Environ Contam Toxicol 64:357-376

Sanliyuksel Yucel D, Yucel MA, Baba A (2014) Change detection and visualization of acid mine lakes using time series satellite image data in geographic information systems (GIS): Can (Canakkale) County, NW Turkey. Environ Earth Sci 72:4311-4323

Sasaki K, Tsunekawa T, Ohtsuka T, Konno H (1995) Confirmation of sulfur-rich layer formed on pyrite after dissolution by $\mathrm{Fe}$ (III) ions around $\mathrm{pH}$ 2. Geochim Cosmochim Acta 59:3155-3158

Schippers A (2004) Biogeochmistry of metal sulfide oxidation in mining environments, sediments and soils, sulfur biogeochemistry-past and present. In: Amend JP, Edwards KJ, Lyons TW (eds) Geological Society of America, pp 49-62

Schippers A, Sand W (1999) Bacterial Leaching of metal sulfides proceeds by two indirect mechanisms via thiosulfate or via polysulfides and sulfur. Appl Environ Microbiol 65:319-321

Schippers A, Jozsa PG, Sand W (1996) Sulfur chemistry in bacterial leaching of pyrite. Appl Environ Microbiol 62:3424-3431

Schippers A, Breuker A, Blazejak A, Bosecker K, Kock D, Wright TL (2010) The biogeochemistry and microbiology of sulfidic mine waste and bioleaching dumps and heaps, and novel Fe(II)oxidizing bacteria. Hydrometallurgy 104:342-350

Schwertmann U, Carlson L (2005) The $\mathrm{pH}$-dependent transformation of schwertmannite to goethite at 25 C. Clay Miner 40:63-66

Seal RR (2003) Stable-isotope geochemistry of mine waters and related solids. In: Jambor JL, Blowes DW, Ritchie IM (eds) Environmental aspects of mine wastes. Short Course Series, Mineralogical Association of Canada, pp 303-334

Seal RR, Hammarstrom JM, Johnson AN, Piatak NM, Wandless GA (2008) Environmental geochemistry of a Kuroko-type massive sulfide deposit at the abandoned Valzinco mine, Virginia, USA. Appl Geochem 23:320-342

Shevenell L, Connors KA, Henry CD (1999) Controls on pit lake water quality at sixteen open-pit mines in Nevada. Appl Geochem 14:669-687

Silva LFO, Izquierdo M, Querol X, Finkelman RB, Oliveira MLS, Wollenschlager $\mathrm{M}$ et al (2011a) Leaching of potential hazardous elements of coal cleaning rejects. Environ Monit Assess 175:109-126

Silva LFO, Oliveira MLS, Neace ER, O'Keefe JMK, Henke KR, Hower JC (2011b) Nanominerals and ultrafine particles in sublimates from the Ruth Mullins coal fire, Perry County, Eastern Kentucky, USA. Int J Coal Geol 85:237-245

Singer PC, Stumm W (1968) Kinetics of the oxidation of ferrous iron. Symposium on coal mine drainage research. Pittsburgh, PA, pp 12-34

Singer PC, Stumm W (1970) Acidic mine drainage: the rate determining step. Science 167:1121-1123

Siyako M, Burkan KA, Okay AI (1989) Tertiary geology and hydrocarbon potential of the Biga and Gelibolu Peninsulas. Bull Turk Assoc Petrol Geol Bull 1:183-199

Smith JW, Batts BD (1974) The distribution and isotopic composition of sulfur in coal. Geochim Cosmochim Acta 38:121-133
Smuda J, Dold B, Spangenberg JE, Pfeifer HR (2008) Geochemistry and stable isotope composition of fresh alkaline porphyry copper tailings: implications on sources and mobility of elements during transport and early stages of deposition. Chem Geol 256:62-76

Sracek O, Choquette M, Gélinas P, Lefebvre R, Nicholson RV (2004) Geochemical characterization of acid mine drainage from a waste rock pile, Mine Doyon, Québec, Canada. J Contam Hydrol 69:45-71

SRK Consulting (2012) Preliminary economic assessment technical report for the Halilaga Project, Turkey. Report Prepared for Truva Bakir Maden Isletmeleri Inc. and Pilot Gold Inc. Report Prepared by SRK Consulting, Canada

Sulzman EW (2007) Stable isotope chemistry and measurement: a primer. In: Michener R, Lajtha K (eds) Stable isotopes in ecology and environmental science. Blackwell, pp 1-21

Swaine DJ (1990) Trace elements in coal. Butterworths, London

Taylor BE, Wheeler MC (1994) Sulfur and oxygen isotope geochemistry of acid mine drainage in the Western United States. In: Alpers CN, Blowes DW (eds) Environmental geochemistry of sulfide oxidation. American Chemical Society Symposium Series, pp 481-514

Taylor BE, Wheeler MC, Nordstrom DK (1984a) Isotope composition of sulphate in acid mine drainage as measure of bacterial oxidation. Nature 308:538-541

Taylor BE, Wheeler MC, Nordstrom DK (1984b) Stable isotope geochemistry of acid mine drainage: experimental oxidation of pyrite. Geochim Cosmochim Acta 48:2669-2678

Tempel RN, Shevenell LA, Lechler P, Price J (2000) Geochemical modeling approach to predicting arsenic concentrations in a mine pit lake. Appl Geochem 15:475-492

Trettin R, Glaser HR, Schultze M, Strauch G (2007) Sulfur isotope studies to quantify sulfate components in water of flooded lignite open pits-Lake Goitsche, Germany. Appl Geochem 22:69-89

Tuncali E, Ciftci B, Yavuz N, Toprak S, Koker A, Aycik H, Gencer A et al (2002) Chemical and technological properties of Turkish tertiary coals. Mineral Research \& Exploration General Directorate Publication, Ankara

United States Environmental Protection Agency (2012) Edition of the drinking water standards and health advisories United States Environmental Protection Agency. https://rais.ornl.gov/docu ments/2012_drinking_water.pdf

Van Everdingen RO, Krouse HR (1985) Isotope composition of sulphates generated by bacterial and abiological oxidation. Nature 315:395-396

Van Stempvoort DR, Krouse HR (1994) Controls of $\delta^{18} \mathrm{O}$ in sulfate: Review of experimental data and application to specific environments. In: Jambor JL, Blowes DW, Ritchie IM (eds) Environmental aspects of mine wastes., Short Course SeriesMineralogical Association of Canada, Ottawa, pp 447-479

Vithana CL, Sullivan LA, Burton ED, Bush RT (2015) Stability of schwertmannite and jarosite in an acidic landscape: prolonged field incubation. Geoderma 240:47-57

World Health Association (2011) Guidelines for drinking-water quality (4th ed). http://apps.who.int/iris/bitstream/10665/44584/ 1/9789241548151_eng.pdf

Yigit O (2012) A prospective sector in the Tethyan metallogenic belt: geology and geochronology of mineral deposits in the Biga Peninsula, NW Turkey. Ore Geol Rev 46:118-148

Yucel MA, Sanliyuksel Yucel D, Baba A (2013) Determining and monitoring of acid mine lakes using satellite images and geographic information system (GIS) in Can County, NW Turkey. 40th IAH Congress, Perth, p 195 